University of Louisville

ThinkIR: The University of Louisville's Institutional Repository

Electronic Theses and Dissertations

1939

\title{
Oxidation potentials of ferric ammonium citrate.
}

Daniel P. Knopf 1916-1991

University of Louisville

Follow this and additional works at: https://ir.library.louisville.edu/etd

Part of the Chemistry Commons

\section{Recommended Citation}

Knopf, Daniel P. 1916-1991, "Oxidation potentials of ferric ammonium citrate." (1939). Electronic Theses and Dissertations. Paper 1814.

https://doi.org/10.18297/etd/1814

This Master's Thesis is brought to you for free and open access by ThinkIR: The University of Louisville's Institutional Repository. It has been accepted for inclusion in Electronic Theses and Dissertations by an authorized administrator of ThinkIR: The University of Louisville's Institutional Repository. This title appears here courtesy of the author, who has retained all other copyrights. For more information, please contact thinkir@louisville.edu. 


\title{
UNT VERSITY OF LOUTSVILLE
}

\section{OXIDATION POTENTIALS OF FERRIC AMMONIUM CITRATE}

\author{
A Dissertation \\ Submitted to the Faculty \\ of the Graduate School of the University of Louisvillo \\ In Fartial Fulfillment of the \\ Requirements for the Degree \\ Of Waster of Science
}

Department of Chemistry

By

Daniel P. Fnopf

Year

1939 


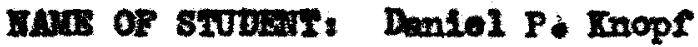

ITLS. OF IIESIS, Osdation Potentiale of Porrio Anoulum Citrato

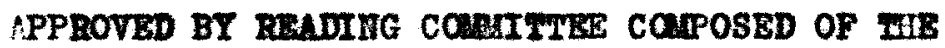

FOLLOWIMG MEABERS:

HAUE OF DIRBCTOR:

mrs: $7 / 21 / 39$ 
Page

I. Introduction ........... 1

II. Calibration of Apparatus

and Theory Involved........ 3

III. Theory . . . . . . . . 14

IV. Experimental .......... 17

a. Experiment No. 1......... 20

b. Experiment Ho. 2-3....... 27

c. Experiment No.4........ 32

d. Experiment No. 5....... 35

e. Experiment jo.6....... 38

f. Experiment No.7......... 41

g. Experiment No. 8......... 45

h. Experiment No.9....... 50

i. Experiment No. 10 ....... 54

j. Experiment No. 11 ....... 58

k. Experiment No. 12 ....... 62

1. Experiment No. 13-14-15 ..... 65

j. Experiment No.16-17...... 69

V. Summation. ......... 73

VI. Bibliography .......... 75

VII. Acknowledgment . . . . . . . 77 


\section{LIST OF GRAPHS}

Page

Fig. I.......... 18

Fig. II . . . ........ 19

Fig. III............. 23

FiE. IV ............. 24

FIg. V .............. 25

Fig. VI ........ 26

Fig. VII........... 31

Fig. VIII .......... 34

Fig. IX ............... 37

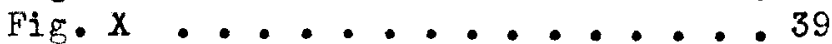

Fig. XI........... 40

Fig. XII............ 43

Fig.XIII ..............44

Fig. XIV............ 48

Fig. XV ........... 49

Fig. XVI ............ 52

Fig. XVII ............. 53

Fig. XVIII. ...........56

Fig. XIX........... 57

Fig. XX ........... 60

Fig.XXI.............61

Fig. XXII............ 64

Fig. XXIII. ...........68

**************

********* 


\section{NTRODUCTION}

The work done on ferric armonium citrate was brought about through an interest in its uses as a sensitizer in the blueprint field. This compound is used to give a greenish tint to the blueprints.

The principle of the blueprint is very simple. Herschel founc that certain salts of iron-the ferric saltswhen exposed to light in the presence of organic matter, were reduced to ferrous salts, and thereby became powerful reducers of other metallic salts wich were unaffected by the unaltered ferric salts. A paper sensitized with ferric armonium citrate and exposec - to sunlicht uncer $\theta$ reoative will be affected only where the negative is nore or less transperent. The light will reach this rart and reduce the ferric salt. The naper is then dipped in a potassium ferricyanide solution and the part that was exposed reacts quickly to form a deep issolukle blue pigment. The unexpozed ferric salts are unaffected and can be washed away. (22)

Ferric anmonium citrate has also medicinal purooses. The crinary soluble ferri salts precipitate roteins readily and are therefore styptic, astringent, and even corrosivo. (20) This salt in contrast (ferric arrocium citrate) is a pleasant chalybeate being rractically free from astrigency or local irritant action. (25) It also may be applied to ulcers 
where it precipitates the proteins and checks oozing and hemorrhages. Ferricamonium citrate is also used to treat anemia. It tends to bring about an increase in the number of circulating red blood cells or an increase in their hemo-globin content. Benefits from its use in maleria, amenorrhea and consumption is probably linked up with the asoociation of anemie with these conditions. (4)

This research is on the oxidation potentials of ferric anmonium itrate and the effect of certain conditions on these potentials. The suggestion for this type of work came when it was noticed in a blueprinting establishment thet there were no controls for the various solutions and only rule of thumb methods prevailed. This was not a research in blueprinting. It was, however, a study in a field closely related to the problems of the blueprinting field. 
CALIBRATION OF AFPARAPUS \& THEORY INVOLVED

The apparatus used in this work which was more or less vital to the correctness of the results was (1) set of weights - chromium plated, class S; (2) 50 cubic centimeter burette; (3) potentiometer and saturated calomel electrode; (4) Class Electrode.

The weights were calibrated with a one gram golc-plated weight, which had been previously calibrated by the Bureau of Standards. As the set of weights used were Class S, this set was designed for high grade analytical and assay weights, thus the tolerances were as follows:

\begin{tabular}{|c|c|c|}
\hline Denomination & Tolerance & $\begin{array}{l}\text { May be either } \\
\text { positive or }\end{array}$ \\
\hline 508. & $0.3 \mathrm{mg}$. & \\
\hline $20 \mathrm{~g}$ & $0.2 \mathrm{mg}$. & \\
\hline $10 \mathrm{~g}$ & $0.15 \mathrm{mg}$. & . \\
\hline $5 \mathrm{~g}$ & $0.15 \mathrm{mg}$. & \\
\hline 25 & $.0 .10 \mathrm{mg}$. & V \\
\hline $1 g$. & $0.10 \mathrm{mg}$. & \\
\hline $500 \mathrm{mg}$. & $0.05 \mathrm{mg}$ & \\
\hline $200 \mathrm{mg}$ & $0.05 \mathrm{mg}$. & \\
\hline $100 \mathrm{mg}$ & $0.05 \mathrm{mg}$. & \\
\hline $50 \mathrm{mg}$. & $0.03 \mathrm{mg}$. & \\
\hline $20 \mathrm{mg}$. & $0.03 \mathrm{mg}$ & \\
\hline $10 \mathrm{mg}$. & $0.02 \mathrm{mg}$ & \\
\hline
\end{tabular}


Denomination (cont'd)

$5 \mathrm{~ms}$.

2 mg.

$1 \mathrm{mg}$.
Tolerance (con'd)

$$
\begin{aligned}
& 0.02 \mathrm{mg} \cdot \\
& 0.01 \mathrm{mg} \text {. } \\
& 0.01 \mathrm{rg} \text {. }
\end{aligned}
$$

The method used to cheok these weights was somewhat similar to that sugeested by Richards in the Journal of American Chemical Society, vol. 22, pp. 44 (1900). Instead of a

\begin{tabular}{|c|c|c|c|}
\hline Denomination & Value & Deviation & Allowed Tolerance \\
\hline $50 \mathrm{~g} \cdot$ & $50.0000 \mathrm{~g}$ & $0.0 \mathrm{mg}$ & $0.3 \mathrm{mg}$. \\
\hline $20 \mathrm{~g} \cdot$ & $20.0001 \mathrm{~g}$ & $0.1 \mathrm{mg}$. & $0.2 \mathrm{mg}$ \\
\hline $10 \mathrm{~g}$. & $10.0000 \mathrm{~g}$ & $0.0 \mathrm{mg}$. & $0.15 \mathrm{mg}$. \\
\hline $10 \mathrm{~g}$. & $10.0001 \varepsilon$ & $0.1 \mathrm{mg}$. & $0.15 \mathrm{mg}$. \\
\hline $5 g$. & $4.9098 \mathrm{~g}$ & $0.2 \mathrm{mg}$. & $0.15 \mathrm{mg}$. \\
\hline $2 \xi \cdot(\operatorname{dot})$ & $2.0000 \mathrm{~g}$ & $0.0 \mathrm{mg}$. & $0.10 \mathrm{mg}$. \\
\hline $2 g$ & $2.0000 \mathrm{~g}$ & $0.0 \mathrm{mg}$. & $0.10 \mathrm{mg}$. \\
\hline 15 & $1.0000 \mathrm{~g}$ & $0.0 \mathrm{mg}$ & $0.10 \mathrm{mg}$. \\
\hline $500 \mathrm{mg}$. & $0.5000 \mathrm{~g}$ & $0.0 \mathrm{mg}$ & $0.05 \mathrm{mg}$. \\
\hline $200 \mathrm{mg}$ & $0.2000 \mathrm{~g}$ & $0.0 . \mathrm{mg}$ & $0.05 \mathrm{mg}$ \\
\hline $100 \mathrm{mg}$. & $0.1000 \mathrm{~g}$ & $0.0 \mathrm{mg}$. & $0.03 \mathrm{mg}$ \\
\hline $100 \mathrm{mg}$ & $0.1000 \mathrm{~g}$ & $0.0 \mathrm{mg}$. & $0.03 \mathrm{mg}$ \\
\hline $50 \mathrm{mg}$. & $0.0500 \mathrm{~g}$ & $0.0 \mathrm{mg}$. & $0.03 \mathrm{mg}$. \\
\hline
\end{tabular}
the gram weight, however, the one gram Eureau of Standard's weight was used. This method gave the following values: 


\begin{tabular}{|c|c|c|c|c|c|}
\hline Denomi nation & Value & & Deviation & Al lowed & Tolerance \\
\hline $20 \mathrm{mg}$. & 0.0200 & g. & $0.0 \mathrm{mg}$. & 0.03 & mg. \\
\hline $10 \mathrm{mg}$. & 0.0100 & $g$. & $0.0 \mathrm{mg}$. & 0.02 & $\mathrm{mg}$. \\
\hline $10 \mathrm{mg}$. & 0.0100 & g. & $0.0 \mathrm{mg}$. & 0.02 & $\mathrm{mg}$. \\
\hline $5 \mathrm{mg}$. & 0.0050 & $g$. & $0.0 \mathrm{mg}$. & 0.02 & $\mathrm{mg}$ \\
\hline $2 \mathrm{mg}$. & 0.0020 & $g$. & $0.0 \mathrm{mg}$. & 0.01 & $\mathrm{mg}$. \\
\hline $2 \mathrm{mg}$. & 0.0020 & g. & $0.0 \mathrm{mg}$ & 0.01 & $\mathrm{mg}$. \\
\hline
\end{tabular}

These weights were, therefore, with one exception within the required accuracy at read values for analytical work. Nevertheless the calibrated value was used in all work.

The burette used wes calibrated against a burette arproved by the Bureau of Standards. As the water was the same temperature in both the burette being calibrated and the Bureau of Standards' burette, no provisions were necessary to take care of the expansion of water caused by heat.

Standard

First Reading Second Reading

0 -c.c. - $50 \mathrm{c.c.}(50 \mathrm{ml}) \quad .0.1 \mathrm{c.c} .-50 \mathrm{c.c} .(49.9$ c.c.)

o c.c. - 40 c.c. $(39.99 \mathrm{ml}) 10.1 \mathrm{c.c} . \quad-50 \mathrm{c.c} .(39.9 \mathrm{c.c.})$

o c.c. - $30 \mathrm{c.c} \cdot(29.98 \mathrm{ml}) .20.1 \mathrm{c.c} . \quad-50 \mathrm{c.c.}(29.9 \mathrm{c.c}$.

0 c.c. $\quad 20$ c.c. $(20.01 \mathrm{ml}) .30.0 \mathrm{c.c} .-50 \mathrm{c.c} .(20 \mathrm{c.c.})$

0 c.c. - $10 \mathrm{c.c} \cdot(10.00 \mathrm{ml}) .40.0 \mathrm{c.c} .-50 \mathrm{c.c} \cdot(10 \mathrm{c.c}$.

50 c.c. -39.95 c.c. $\left(10.05\right.$ c.c.) 0 c.c. $-10 c_{.0 .}(10$ c.c.) 
Standard $\left(\operatorname{con}^{\prime} t\right)$

First Reading Second Reading

$39.95 \mathrm{c.c}$. 29.98 c.c. $\left(9.97 c_{. c .}\right) 10$ c.c.

$29.98 \mathrm{c.c}$.

$19.95 \mathrm{c.c}$.

$10.00 \mathrm{c.c}$.
Celibrated Burette (con't)

First Reading Second Reading

$20 \mathrm{c.c} \cdot(10 \mathrm{c.c} \cdot)$

$30 \mathrm{c.c} \cdot(10 \mathrm{c.c.})$

40 c.c. $(10 \mathrm{c.c}$.

$50 \mathrm{c.c} \cdot(10 \mathrm{c.c}$.

In all work with the burette that required accuracy, the known value was used rather than the face value. Thus in all titrations the known rather than that of the fece value was used while in such work as making up solutions, the face value was used. There was one exception to this-in making up the ferric armonium citrate accurate measuring was used both in regards to woight of material used and as to the amount of liquid in the olution. This was necessary for thore was no practical method at hand to compute its oxidizing normality.

The potentionmeter used was made by Leeds and Northrup Comrany. It was used in conjunction with a aturated Calomel coll. The principle of the potentiometer is reasonably simple. The method used was that of Poggendorff. (23) 
POTENTIONETER

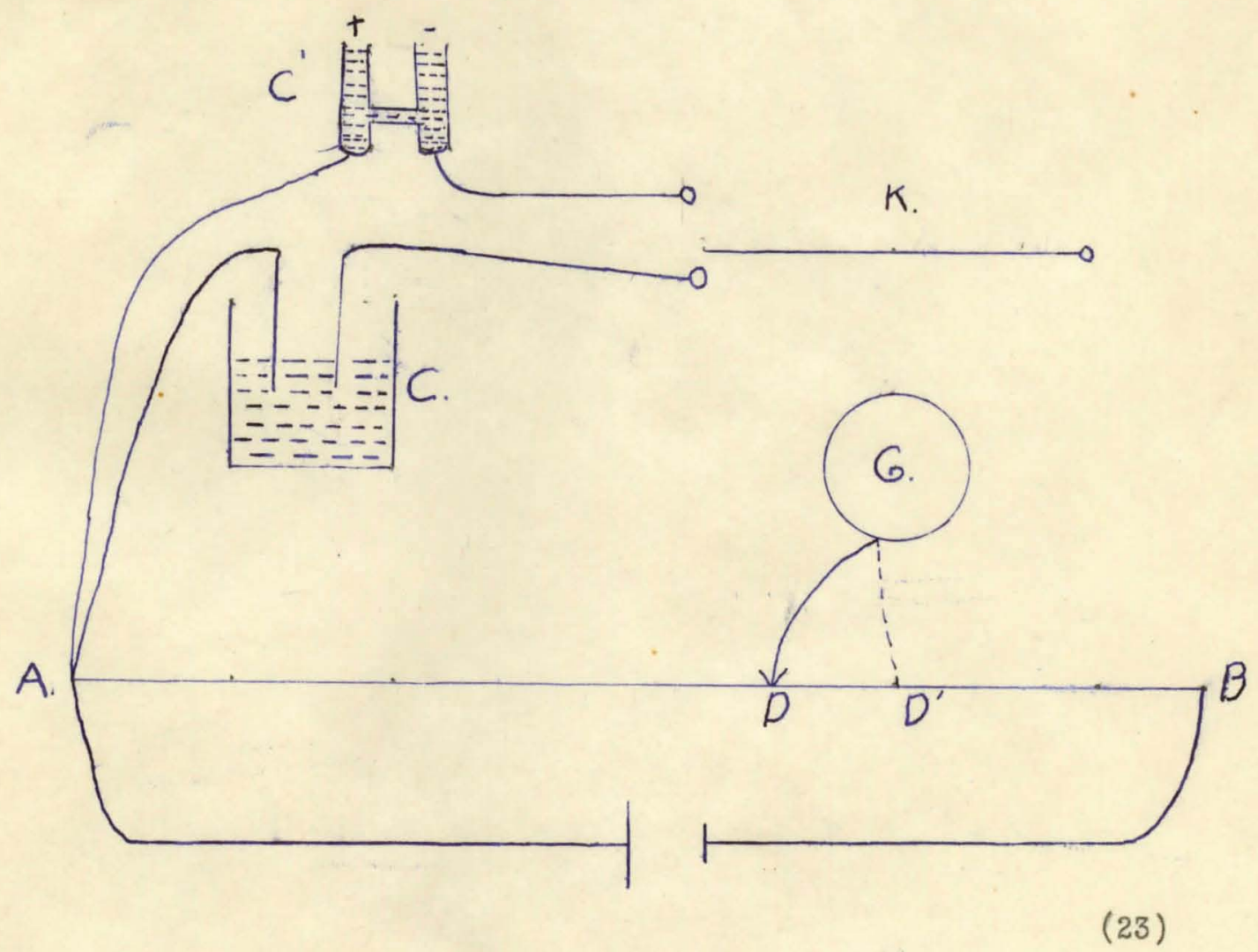

- It is probably the simplest and most accurate in cases where the cell is too easily polarized to allow taking direct readings. 
This method depends unon balancin the unlonom arainst a lnow electronotive force. It is illustrated in the figure on the proceedin pase. $A B$ represents a wire strotched on a meter scale, U- an approximate two volt dry cell, C- the cell to be measured, $D-$ a ealvanometer, and $I$ a kev. Tho two cells must be conncted so as to oppose each other, thouch both negative poles could be connected to $A$. The measurement consists in findinc the position on the bride of the sliding contact $D$ where there is no deflection of the galvanometer when the key is closed. Then if the wire is of uniform resistence throuchout, the ractional part of the wire $A D / A B$ is that part of the electromotive force of $Y$ that equals the electromotive forco of $C$; that is - $A D / A B$ times the electromotive force of $V$ equals the electronotive force of C. (23) These operations, hovever, are carried on by a potentioneter of more convenient desinn, but its functions are not as easily illustreted. The slide wire of the illustrated ficure, $A B$ is arranced as a circular coil an D remains stationary. Rotation of the coil then changes the distance AD. To extend the rance of the resistance and to fecilitate readins, thero are two sets of coils in series. The resistence of one of the coils is equal to ono division of the other ond is itself divided into 1000 equal parts. By movin ontacts in two coils, it is possible to pick 
off part of this resistance (corresponding to $A D$ of the figure) and balance the corresponding fall of potential against either the standard cell $\mathrm{C}^{\prime}$ or the unknown voltage $\mathrm{E}$ using the galvanometer. A double-pole, double-throw switch facilitates the shifting from the standard cell to the cell which is to be measured. (7) $V$ is not a standard cell, but only one which should remain constant during the measurement. In order to get a comparison with a standard cell, $C^{\prime}$, a new balance is found at $D^{\prime}$. Then $A D: A D^{\prime}=$ e.m. $f$. of $C:$ : $\theta \cdot m \cdot f \cdot$ of $c^{\prime} \cdot$

The standard cell that was used in the potentiometer used in this work was a Weston Cell which had an approximate value of $1.0183 \mathrm{v}$. The equation representing the true value from zero degrees to forty degrees is $-E=1.0183-0.00004075$ $(t-20)-0.000000944(t-20)^{2} 0.0000000098(t-20)^{3}$

This 0011 consists of:

$\begin{array}{lllll}\text { 10-15\% Cd amalgam } & \mathrm{CdSO}_{4} \text { paste } & \mathrm{HgSO}_{4} \text { Paste } & \\ & \text { satd. } \text { Cdn. } & \text { sata. } & \text { ooln. } & \mathrm{Hg}\end{array}$ The above equation shows that the temperature coefficient of the electrorotive force of the Weston cell for most practical purposes is zero. For this reason and also because of its constancy, this cell is the most widely used standard in electronctive force measurements. The effects of aging are small and amount to but a few microvolts per year. (5) 
In order to measure the potential difference at a metal-solution junction, it was necessary to have another metal solution junction or "half-element" of known potential difference. Such metal solution junctions are termed standard electrodes. (5) Usually either a normal or deci-normal calomel electrode is used, if one is using this type of cell. However, it was found more convenient to use the saturated potassium chloride-calomel cell. In this research, this cell seemed to be more easily duplicable and thus aided in the accuracy of the research. It was necessary to prepare an entirely new cell, as adding just saturated potassium chloride to an old already prepared cell, Eives questionable accuracy. One investigator (6) noticed that the value of the cell was not appreciably changed by just adding fresh potassium chloride. He found that it was necessary to also add fresh calomel and mercury to the cell. One case wes cited as an illustration: a0.1 calomel cell $\mathrm{B}_{6}$ was employed in combination 6 and gave an observed value for the combination at twenty-five degrees of 0.3934 volt (theory $=0.4016$ volt.) When the potassium chloride solution in the cell had been replaced by some fresh solution, the value of the combination was 0.3935 volt. The entire contents of the cell were then removed, the cell thoroughly cleaned and prepared again with all fresh materials. The resulting value of the combination was 0.4015 . (6) This 
would secm to indicate that whenever a new cell is prepared, an entire chance of naterials must be effected if accurate Viues are desired. These same investigators after intensive study came to the conclusion that the saturated potassium chloride-calomel cell is the best cell for use in conjunction with a saturated salt bridee, because it has a very small temperature coefficient, is easily reproducible, can safely be used at temperatures from 5 degrees to $60^{\circ}$, and can be relicd upon for its constancy of value over long periods of time. (6) Since for this type of wor it was necessary to use a saturated potassium chloride-agar bridge, the saturated potassium chloride-calomel coll was the logical one to use.

The Beclman pH meter or glass electrode was used in this work to determine the degree of acidity or alkalinity of the solution under observation. This type was used for several reasons - the irst nd principal one being that a glass electrode is not poisoned by a strong oxidizing solution as in the hydrogen electrode. One investicator (14) in plottins the chance of electromotive force durin the titration of sulfuric acid and sodium hydroxide, found that this titration followed the course of a similar titration using the hydrogen and quinhydrone electrodes even upon the addition of potassium permangenate to the sulfuric acid. This observation showed that the plass electrode responded only to changes 
in the hydrogen-ion concentration and is not influenced by the powerful oxidation potential produced by the presence of potassium permancanate. (14) The second reason is that the major portion of the solution runs from a pH of 2-8. Thus the glass electrode was practical for the efrects of alkaline solutions in increasing the divergence between the electronotive forces of the rlass and of the $\mathrm{H}_{2} /$ Pt begins to be noticeable at about a pU of 9 ; $i \cdot \theta$. at the point where the buffer action of sodium hydrogen silicate in the gloss would begin to resist the action of alkeline solutions less effectively. since the ap arent first dissociation constant of sulfurous acid is about $10^{-9}$. (11) The rapidly increasing divergence between the two electromotive forces in the presence of sodium end lithium ions begins about at a HI3, and the aprarent second dissociation constant of $\mathrm{H}_{2} \mathrm{SiO}_{3}$ is $10^{-13}$. (II) Beyond this pH it is probable that the surface of the Elass is attacked with increasing rapidity as the solution becomes more alkaline. (12) The Beckman $\mathrm{nH}$ meter carries with it a eraph (with explanation on how to use it) that one uses to calculate pI's greater than 9. Therefore, it is posible to use the glass olectrode for solutions with greater alkalinity than 9. However, it is the opinion of this investigator that for alkaline, non-oxidizing solutions, the hydrogen electrode is far more efficient. Another advantage of the glass electrode is its extreme handiness and convenience of use. 
(12)

The class electrode has been just recently fintroduced although its basic principle that the potential difference between two solutions separated by a flass depends on the hydrcgen-ion concentrations of the solution has been known for quite some time. (10) In a cell of this type:

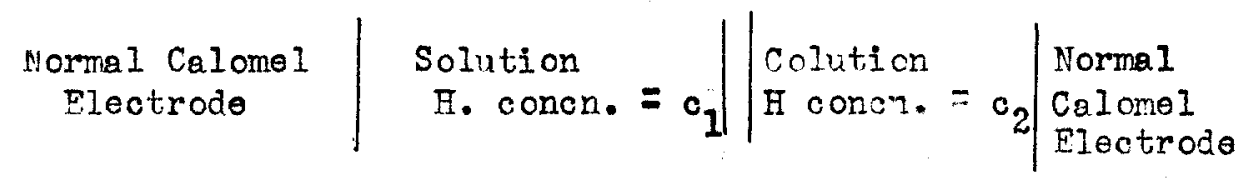

the potentials of the two calomel electrodes cancel one sncther and the clectromotive force of the cells is equal to the potential difference at the glass membrane, a. Prcviched there is no potential in this membrans.

$$
E=\operatorname{Rr} / \mathrm{F} \text { In. } \mathrm{c}_{2} / \mathrm{c}_{1}
$$

If either $c_{1}$ or $c_{2}$ is known the other can be calculatad. However, owing, to differences in the surface of the glass membrene, a small correcticn must be aplied for "asymetry potential" due to the glass. This correction on be sscortained by determining the electrometive force of the cell when the hydrogen-ion concentration of both are known or equal. 
According to modern ideas, oxidation occurs, not only when oxycen is added to a substance, but also whenever electrons or negative charges/withdrawn from, its molecules, atcms or ions. Similarly, reduction consists in the addition of electrons to, or withdramal of positive electricity from the molecules, atoms or ions of a substance. (5).

In order that a relation may be obtained between the olectromotive force of oxidation-reduction cells and the tendency of the components to pass from a lower to a hicher state of oxidation (oxidation), or from a higher to a lower state of oxidation (reduction) let us consider the cell,

$$
\mathrm{Pt}|\mathrm{Fe}+| \mid \mathrm{Hg}_{2}^{++} \text {in } \mathrm{N} \cdot \mathrm{KCl} \mid \mathrm{Hg}_{2} \mathrm{Cl}_{2}-\mathrm{Hg} \cdot
$$

The reaction which takes place in this cell may be reprosented by the equation:

$$
2 \mathrm{Fe}^{++t}+\mathrm{Hg}_{2}=2 \mathrm{Fe}^{++}+\mathrm{Hg}_{2}^{++}
$$

the direction of the reaction depended upon the relative concentration of the reacting substances.

The equilibrium constant of the forecoine reaction is-

$$
\mathrm{K}=\left(\mathrm{Fe}^{++}\right)^{2}\left(\mathrm{HC}_{2}^{++}\right) /\left(\mathrm{Fe}^{+++} \xi\left(\mathrm{Hg}_{2 \mathrm{e}}\right)\right.
$$

where the subscript, e, denotes the equilibrium concentractions. In accordance with the equation for the maximum work (a) that may 
be obtained from a reversible reaction;

$$
A=R T \ln K^{\prime}-\operatorname{RT} \ln \left(\mathrm{F}_{\theta}^{++}\right)^{2}\left(\mathrm{Hg}^{++}\right) /\left(\mathrm{F}_{\theta}^{+++}\right)^{2}\left(\mathrm{HE}_{2}\right)
$$

Further since the concentration of the rercury and the mercurous ions are constant, wo may write:

$$
E=R T / 2 F \ln K^{\prime}-\mathrm{RT} / F \ln \left(F^{++}\right) /\left(F \theta^{t+r}\right)
$$

where

$$
\mathrm{K}=\left(\mathrm{Fe}_{\theta}^{++}\right)^{2} /\left(\mathrm{Fe}_{\mathrm{e}}^{+++}\right),
$$

Setting $\mathrm{RT} / 2 \mathrm{~F}$ InX $=\mathrm{E}_{\mathrm{O}}$ we obtain:

$$
E=E_{0}-\mathrm{RT} / \mathrm{nF} \text { ln. }\left(\mathrm{Fe}^{++}\right) /\left(\mathrm{Fe}^{++t}\right) \text {. }
$$

For any cell,

$$
\text { Pt } \mid \begin{array}{l|l|l}
M^{\prime} & \text { normal hydrogen electrode } \\
\text { or } & \text { normal calomol electrode, }
\end{array}
$$

above equation may be witten in the general form:

$$
\mathrm{E}_{\left(\mathrm{c}_{\mathrm{f}}^{\circ}\right)}-\mathrm{E}_{\mathrm{O}}-\mathrm{RT} / \mathrm{nF} \text { In. } \mathrm{co} / \mathrm{c}^{\prime} \text {, }
$$

Where $\mathrm{E}_{\left(\mathrm{c}^{\circ} \mathrm{C}^{1}\right)}$ is the electromctive force produced by the change of the ions from a higher state of oxidation ( $M$ ) to a lower state of oxidation (MO); $c^{\circ}$ and $c^{\prime}$ are the ionic concentrations in the lower and higher state of oxidation: $E^{\circ}$ is the electromotive force of the cell when $c^{\circ}$ is equal to $c^{\prime}$ and " $n$ " is the difference of the icns. Thiselectromotive force $E$ is csiled the oxidation potential and $E_{0}$ is termed the normal oxidation potential of the electrode Pt $\frac{M}{M}$. (5)

The values of $\mathrm{E}_{0}$ are caloulated on the assumption approximete at west - that the ratio of the concentrations of 
the ferric and ferrous ions are equal to the concentrations of the respective salts. This method of obtaining date was used by Peters' (16), Carters and Clews (2), T. J. Glovers' (9), and others.

Since all oxidation potentials are expressed on the bosis that the tendoncy of hydrocen to pass from the ionic to the atomic is zero, when in contact with a solution which is normal vith respect to hydrogen ions, the electromotive force has been reduced to the hydrogen valuc. Thus the value represontine the oxidation potential, $E$, is referred to that of hydrogen in contact with a normal sclution of its ions at zero. From the value of $E$ thus obtained, the value of the normal oxidation potential $E_{0}$, may be calculated from the equation:

$E=\mathrm{E}_{0}-\mathrm{RT} / \mathrm{nF}$ In. $\mathrm{c}^{0} / \mathrm{c}^{\prime}$ 


\section{EXPERIMENTAL}

This research is an attempt to find the effect of various conditions on the ferri-ferro potential of ferrous ammonium sulphate and ferric ammonium citrate with a buffer potassium oxalate. Various other experimenters (2) (13) (3) (15) have measured the effect of acid, base, temrerature, and concentrations on the ferri-ferro potential itself, but with one exception in the literature, ncne have attempted to measure these effects on a buffered ferri-ferro potential. In this one exception oxidation and reduction buffers were used and it wes found that the potential readings varied from $0.64-0.10$ volts. (It was found in the present set of experiments the veriations in potential were from 0.5423 to 0.015.) The effects of adied amounts of acid $\left(\mathrm{H}_{2} \mathrm{SO}_{4}\right)$ and bases (NaOH) were likewise studied. 


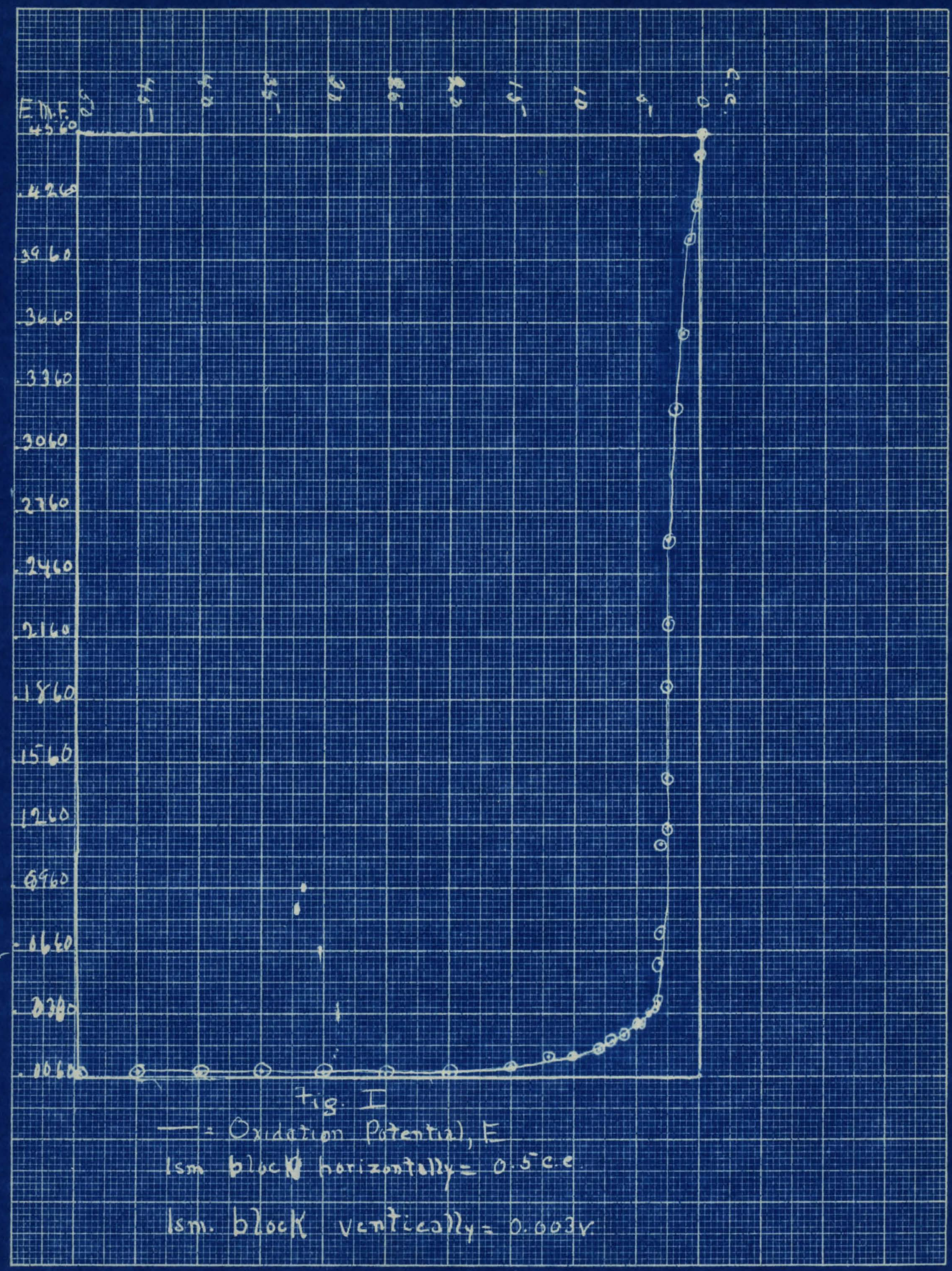




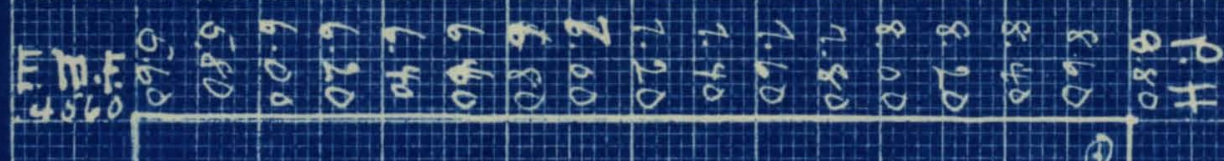

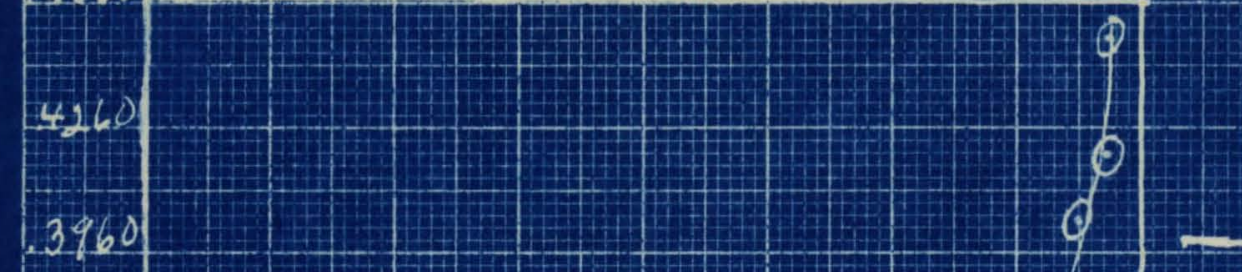

$$
7 \text { II }
$$

.3960

$-3660$

.3360

3060

2160

tim. block verticully $=0.0036$

2460

2160

1860

.1562

H2w

0960

.6860

$-0360$

lote $000-00$. Ism. block horizonta)ly $=0.040 \mathrm{ct}$. 


\section{EXPERTMENT NO. I}

The buffer potassium oxalate was run against the "ferro" solution to check the effect of the buffer with just one of the components of the "ferri-ferro" potential. It was found that the addition of only 3.3 milliliters of ferrous ammonium sulphate caused a loss of $0.3935 \mathrm{~V}$. in the solution. After this loss of oxidation potential in the solution, therewas only a loss of $0.044 \mathrm{v}$. caused by the addition of 46.7 milliliters of ferrous ammonium sulphate. This showeda rather decided break in potential as may be seen on Figure No. 1 on the preceeding page.

The potassium oxalate solution (1N.) was slightly alkaline having a pH of 8.7 , however, the addition of ferrous ammonium sulphate fradually changed the pH towards the acid side. The steady downward progression of $\mathrm{pH}$ showeda curve similar to that of Figure No. 1.

\section{Table No. 1}

$\begin{array}{cccc}\mathrm{Fe}\left(\mathrm{NH}_{4}\right)_{2} & \left(\mathrm{SO}_{4}\right)_{2} \mathrm{~K}_{2} \mathrm{C}_{2} \mathrm{O}_{4} & \mathrm{E} & \mathrm{pH} \\ 0.0 . & 25.00 & 0.4460 & 8.7 \\ 0.5 & 25.00 & 0.4205 & 8.7 \\ 1.0 & 25.00 & 0.4054 & 8.6 \\ \mathrm{Fe}\left(\mathrm{NH}_{4}\right) 2\left(\mathrm{SO}_{4}\right) 2-\mathrm{K}_{2} \mathrm{C}_{2} \mathrm{O}_{4} & & \\ 0.0 . & \text { c.c. } & \mathrm{E} & \mathrm{pH}\end{array}$




\begin{tabular}{|c|c|c|c|}
\hline 1.5 & 25.00 & 0.3620 & 8.5 \\
\hline 2.0 & 25.00 & 0.3240 & 8.45 \\
\hline 2.5 & 25.00 & 0.2625 & - \\
\hline 2.6 & 25.00 & 0.2220 & - \\
\hline 2.7 & 25.00 & 0.1920 & - \\
\hline 2.8 & 25.00 & 0.1485 & - \\
\hline 2.9 & 25.00 & 0.1240 & - \\
\hline 3.0 & 25.00 & 0.1170 & 8.40 \\
\hline 3.1 & 25.00 & 0.0750 & - \\
\hline 3.2 & 25.00 & 0.0610 & - \\
\hline 3.3 & 25.00 & 0.0525 & - \\
\hline 3.4 & 25.00 & 0.0410 & - \\
\hline 3.5 & 25.00 & 0.0410 & 8.36 \\
\hline 4.0 & 25.00 & 0.0360 & 8.29 \\
\hline 4.5 & 25.00 & 0.0315 & 8.28 \\
\hline 5.0 & 25.00 & 0.0315 & 8.28 \\
\hline 6.0 & 25.00 & 0.0265 & 8.12 \\
\hline 7.0 & 25.00 & 0.0230 & 8.10 \\
\hline 8.0 & 25.00 & 0.0185 & 8.05 \\
\hline 10.0 & 25.00 & 0.0163 & 8.00 \\
\hline 12.0 & 25.00 & 0.0163 & - \\
\hline $\begin{array}{c}\left(\mathrm{F} \in\left(\mathrm{NH}_{4}\right)\left(\mathrm{SO}_{4}\right)\right) \\
0.0\end{array}$ & $\left(\mathrm{~K}_{2} \mathrm{C}_{2} \mathrm{O}\right)$ & $\mathrm{E}$ & $\mathrm{pH}$ \\
\hline 15.0 & 25.00 & 0.0116 & 7.55 \\
\hline 20.0 & 25.00 & 0.0085 & 6.89 \\
\hline 25.0 & 25.00 & 0.0085 & 6.60 \\
\hline
\end{tabular}




$\begin{array}{llll}30.0 & 25.00 & 0.0085 & 6.41 \\ 35.0 & 25.00 & 0.0085 & 6.10 \\ 40.0 & 25.00 & 0.0085 & 6.10 \\ 45.0 & 25.00 & 0.0085 & 5.90 \\ 50.0 & 25.00 & 0.0085 & 5.80\end{array}$




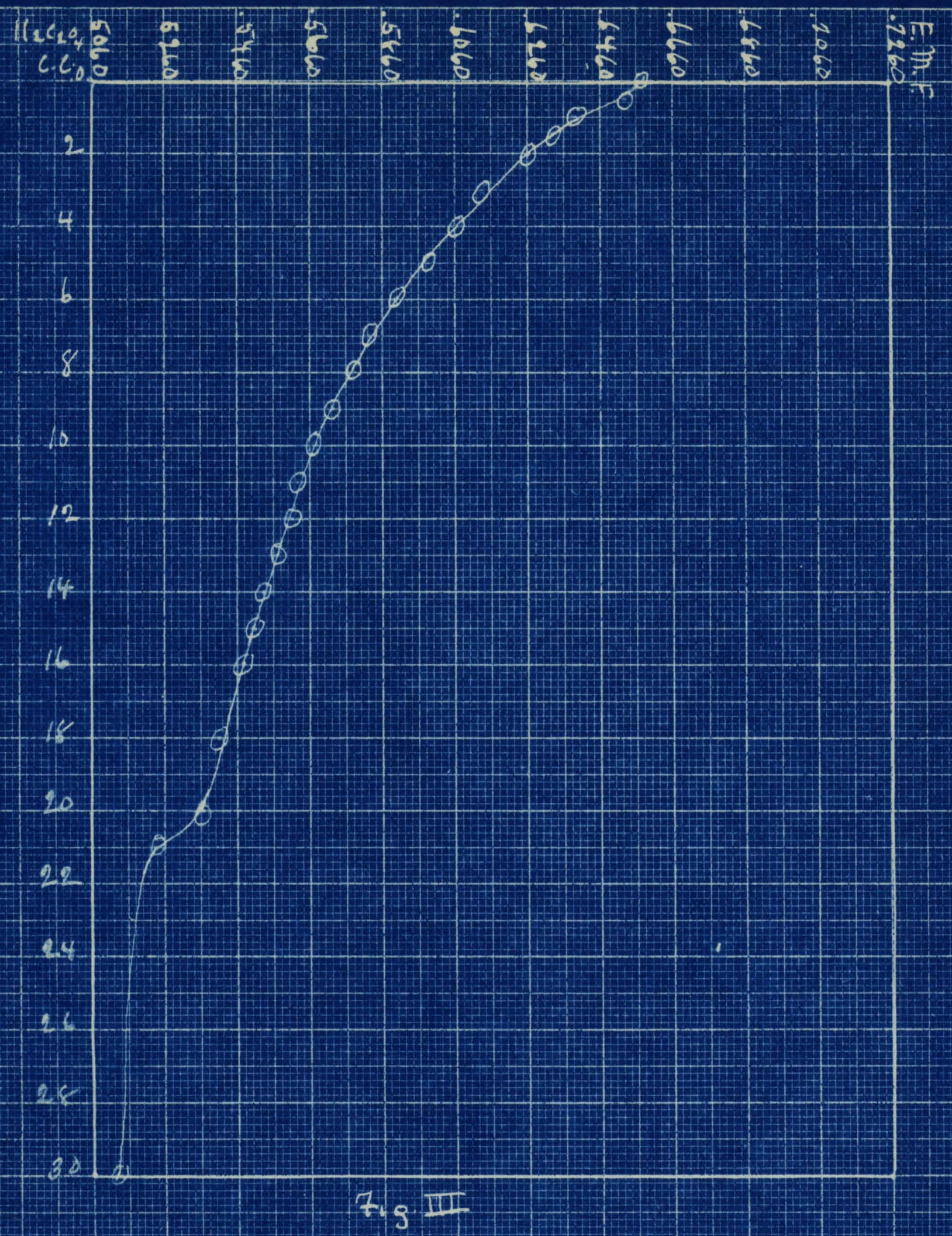

\section{$-=$ Oxidation Potental, E}

$\operatorname{lsm} \cdot$ black horizont.2ly $=0.002 \mathrm{~V}$.

Ism. Hlock verticany $=0.2 a \cdot c_{2} \zeta_{2} c_{2} O_{4}$ 


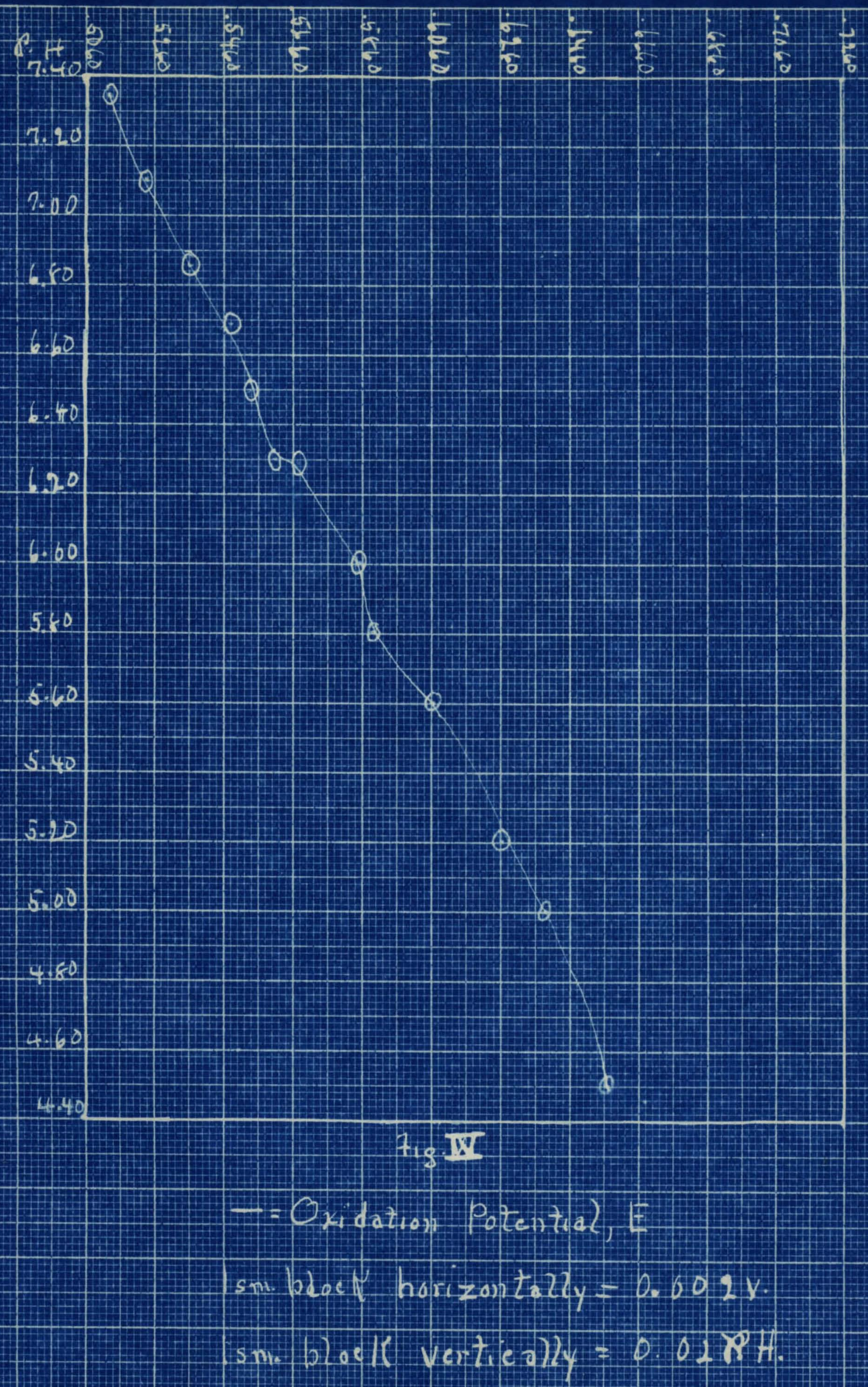




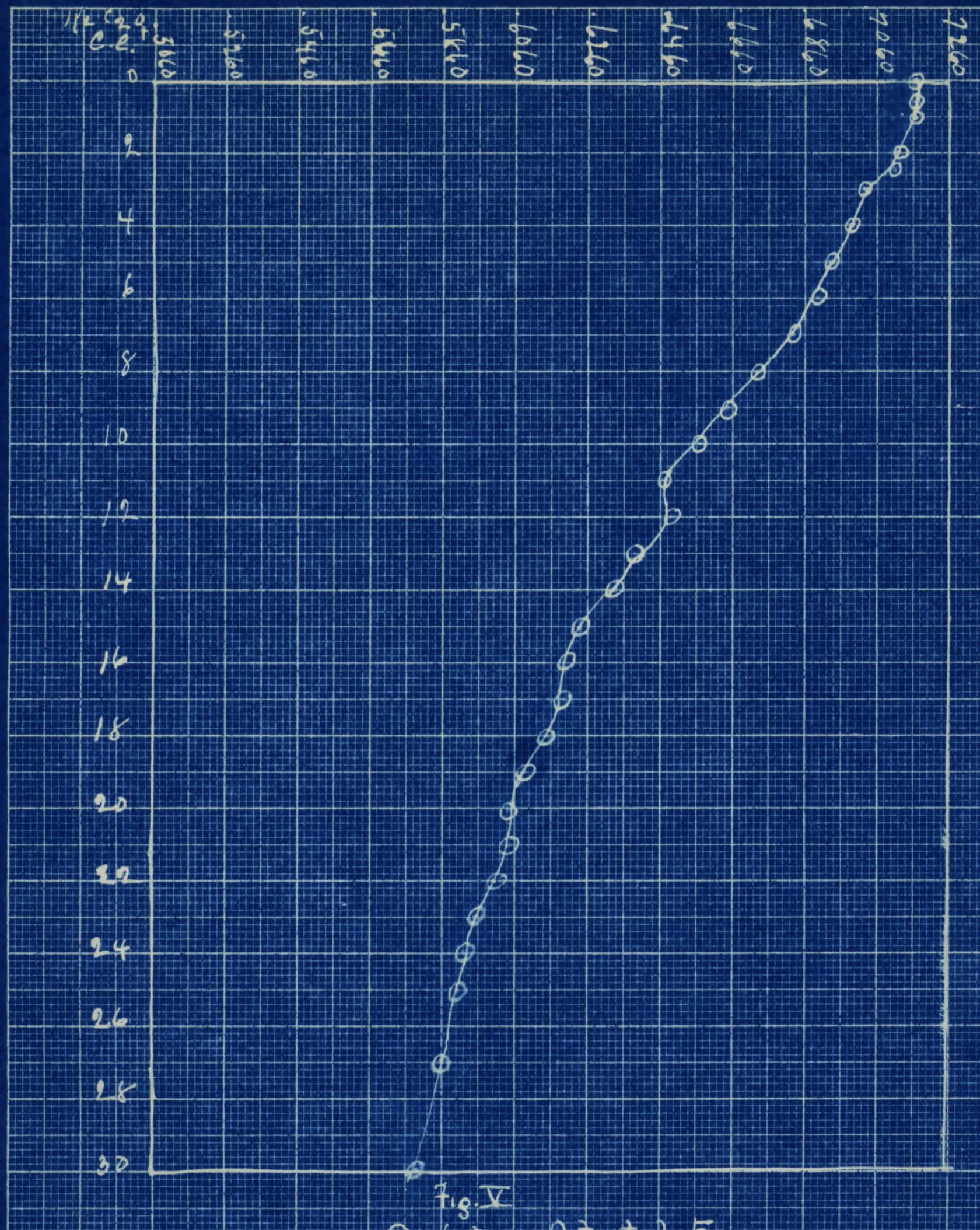

-Oxidation potentia), E

$|\sin . b l o d|$ horizontalzy=0.002V.

Isn. b2ocir vertica)ly $=0.2$ ec 


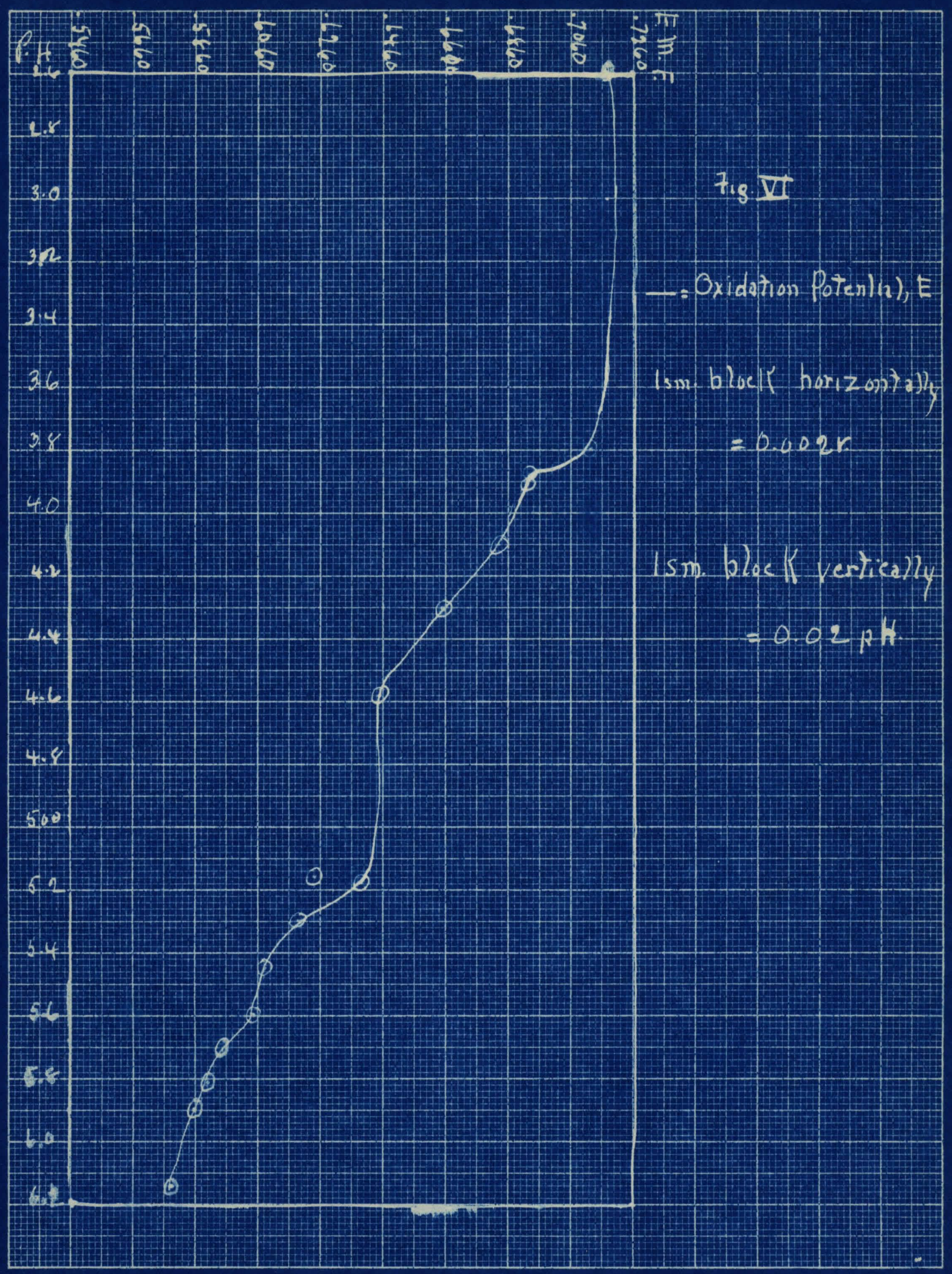


EXPERIMENT NOS. $2 \& 3$

The next step in the problem was to find the effect on the buffer upon the other member of the "ferri-ferro" potential. $30 \mathrm{milliliters}$ of potassium oxalate gas gradually added to $25 \mathrm{mil}$ liliters of ferric ammonium citrate and a reading was taken approximately every cubic centimeter. There was no rapid drop in the oxidation potential and also there was no tapering off, just a steady drop in the potential throughout the whole run.

The addition of $3 \mathrm{milliliters}$ of dilute sulfuric acid and then again the addition of potassium oxalate raised the oxidation potential approximately $0.05 \mathrm{v}$, , but affected little the change in potential upon the addition of potassium oxalate.

The loss in potential in Experiment No. 2 was 0.1438 and the loss in Experiment No. 3 was 0.1385 caused by the addition of 30 cubic centimeters of the buffer potassium oxalate. Thiswas a great deal less than the buffer affected the ferro solution, indicating that the ferric ion is less activated by the buffer.

A curve was then drawn plotting the $p H$ of the aforementicned runs against the oxidation potentials. The first run potassium oxalate against ferric ammonium citrate showed almost a straight line of increasing alkalinity.

The adition of the acid, however, ruined the steady progression toward alkalinity and graph No. 6 did not show as steady a line as the first. 


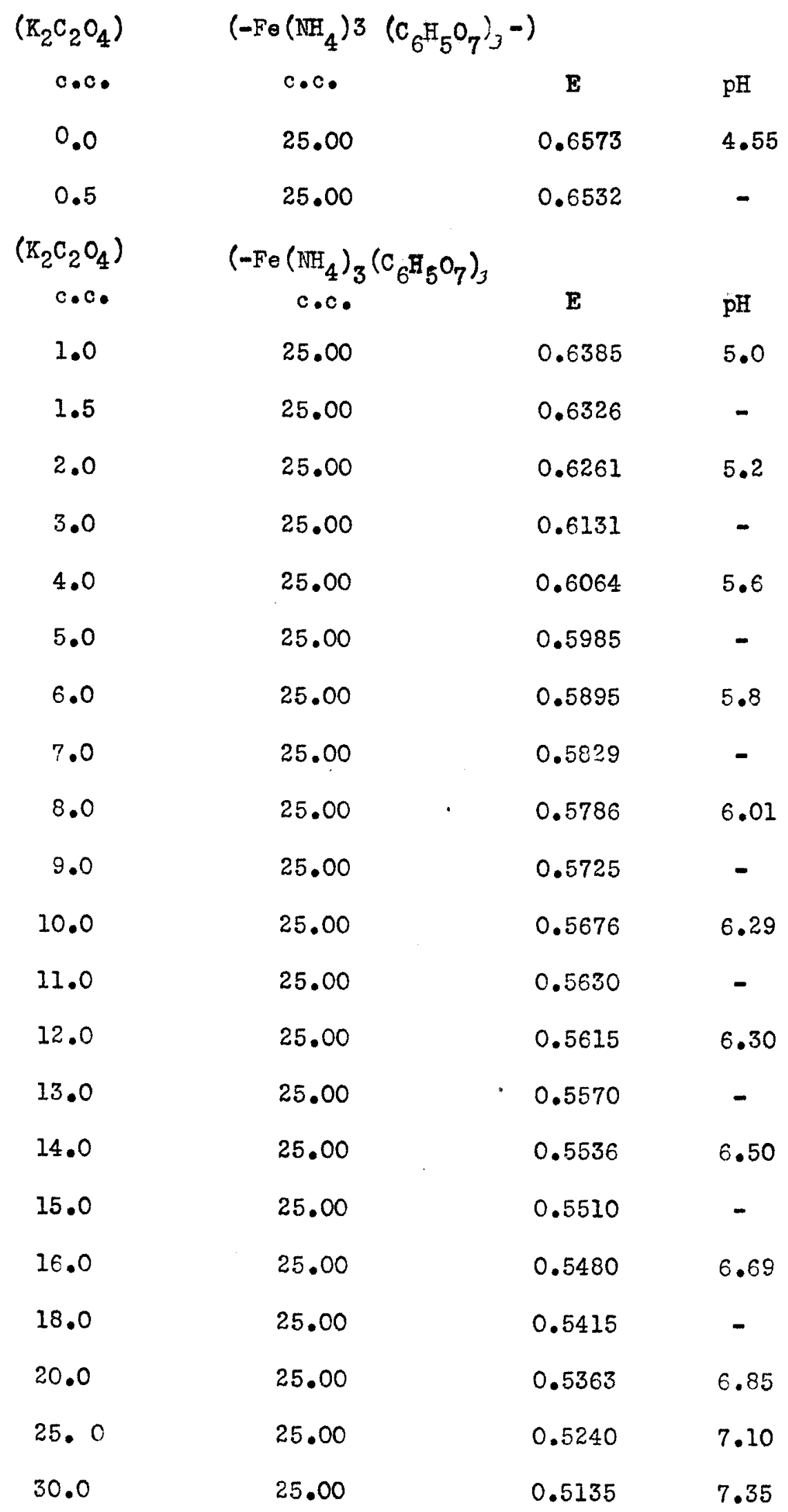


TABLE NO. 3

$\left(3 \mathrm{coc} \cdot{ }^{\prime} \mathrm{s}\right.$ of $\mathrm{H}_{2} \mathrm{SO}_{4}$ )

\begin{tabular}{|c|c|c|c|}
\hline $\left.\mathrm{K}_{2} \mathrm{C}_{2} \mathrm{O}_{4}\right)$ & $\left(-\mathrm{Fe}\left(\mathrm{NH}_{4}\right)_{3}\left(\mathrm{C}_{6} \mathrm{H}_{5} \mathrm{O}_{7}\right)\right.$ & -) & \\
\hline$c \cdot c$ & $c . c$. & $\mathbf{E}$ & $\mathrm{pH}$ \\
\hline 0.0 & 25.00 & 0.7175 & 2.6 \\
\hline 0.5 & 25.00 & 0.7175 & - \\
\hline 1.0 & 25.00 & 0.7175 & - \\
\hline 2.0 & 25.00 & 0.7126 & 3.8 \\
\hline 2.5 & 25.00 & 0.7110 & - \\
\hline 3.0 & 25.00 & 0.7029 & 3.91 \\
\hline 4.0 & 25.00 & 0.6990 & - \\
\hline 5.0 & 25.00 & 0.6937 & 3.88 \\
\hline 6.0 & 25.00 & 0.6891 & - \\
\hline 7.0 & 25.00 & 0.6830 & 4.10 \\
\hline 8.0 & 25.00 & 0.6735 & - \\
\hline 9.0 & 25.00 & 0.6655 & 4.30 \\
\hline 10.0 & 25.00 & 0.6566 & - \\
\hline 11.0 & 25.00 & 0.6465 & 4.58 \\
\hline 12.0 & 25.00 & 0.6480 & - \\
\hline 13.0 & 25.00 & 0.6395 & 5.18 \\
\hline 14.0 & 25.00 & 0.6336 & - \\
\hline 15.0 & 25.00 & 0.6240 & 5.15 \\
\hline 16.0 & 25.00 & 0.6201 & - \\
\hline 17.0 & 25.00 & 0.6190 & 5.30 \\
\hline 18.0 & 25.00 & 0.6151 & - \\
\hline 19.0 & 25.00 & 0.6083 & 5.45 \\
\hline 20.0 & 25.00 & 0.6048 & - \\
\hline
\end{tabular}




$\begin{array}{cccc}\left(\mathrm{K}_{2} \mathrm{C}_{2} \mathrm{O}_{4}\right) & \left(\mathrm{Fe}\left(\mathrm{NH}_{4}\right)_{3}\left(\mathrm{C}_{6} \mathrm{H}_{5} \mathrm{O}_{7}\right)_{3}\right) & & \\ \mathrm{c} . \mathrm{c} . & \mathrm{c.c} & \mathrm{E} & \mathrm{pH} . \\ 21.0 & 25.00 & 0.6048 & - \\ 22.0 & 25.00 & 0.6012 & 5.71 \\ 23.0 & 25.00 & 0.5953 & - \\ 24.0 & 25.00 & 0.5922 & - \\ 25.0 & 25.00 & 0.5902 & 5.81 \\ 27.0 & 25.00 & 0.5860 & 5.90 \\ 30.0 & 25.00 & 0.5790 & 6.15\end{array}$




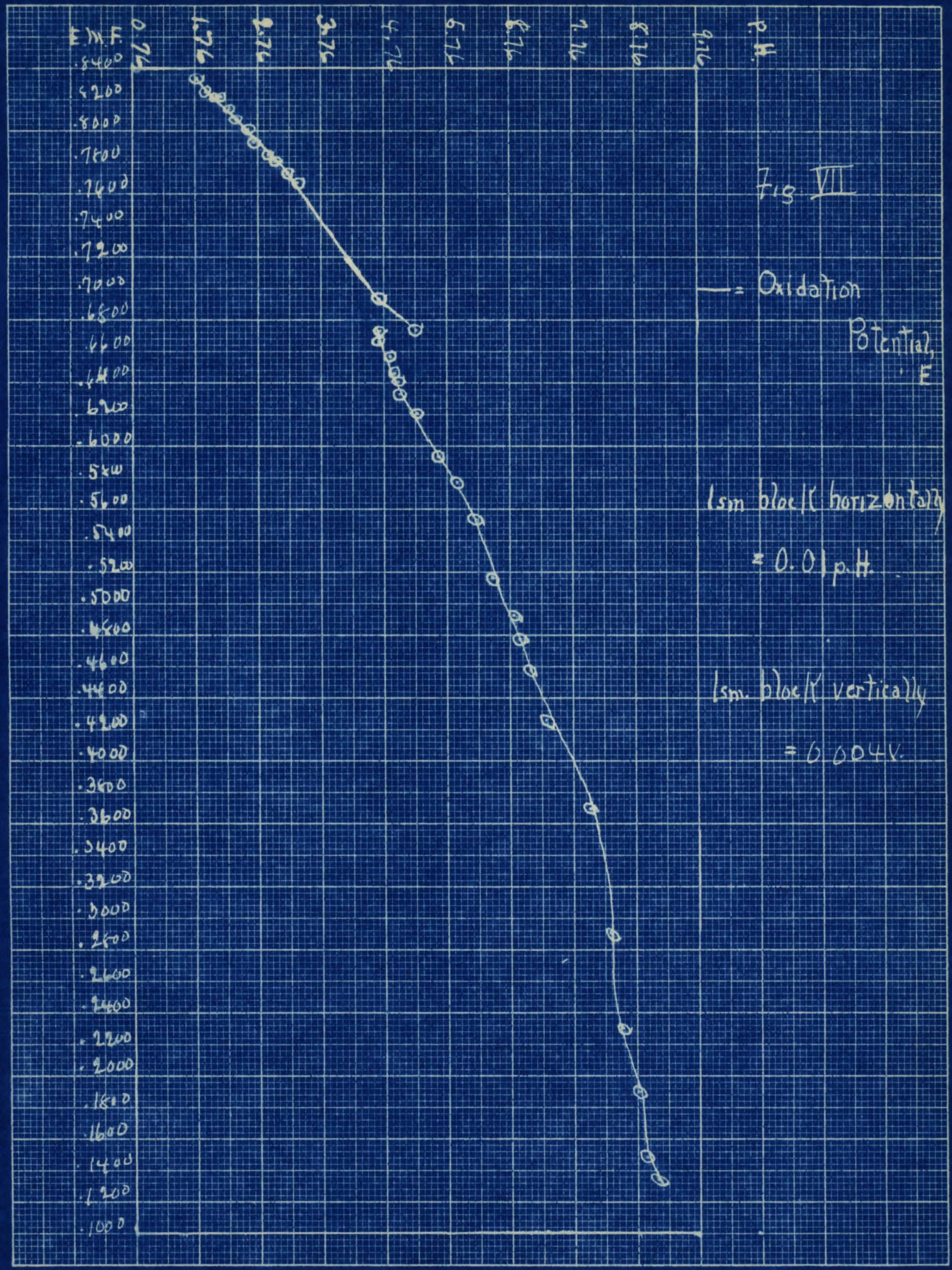


In this run an attempt was made to find the effect of $\mathrm{pH}$ upon the oxidation potential of ferric ammonium citrate. It cen be seen from graph No. 7 that as the pH increased the potential decreased in this compounc. This seemed to indicate that alkalinity tends to decrease the oxidizing power of these compounds.

\begin{tabular}{|c|c|c|c|}
\hline $\mathrm{H}_{2} \mathrm{SO}_{4}(\mathrm{dil})$. & $\left(\mathrm{Fe}\left(\mathrm{NH}_{4}\right)_{3}\left(\mathrm{C}_{6} \mathrm{H}_{5} \mathrm{O}_{7}\right)_{3}\right)$ & & \\
\hline$c . c$. & $c . c$. & E & $\mathrm{pH}$ \\
\hline 0.0 & 25.00 & 0.6750 & 5.2 \\
\hline 0.5 & 25.00 & 0.6937 & 4.65 \\
\hline 1.5 & 25.00 & 0.7670 & 3.89 \\
\hline 2.0 & 25.00 & 0.7741 & 3.22 \\
\hline 2.5 & 25.00 & 0.7825 & 3.05 \\
\hline 3.0 & 25.00 & 0.7865 & 2.91 \\
\hline 4.0 & 25.00 & 0.7950 & 2.71 \\
\hline 5.0 & 25.00 & 0.8020 & 2.61 \\
\hline 7.0 & 25.00 & 0.8090 & 2.45 \\
\hline 10.0 & 25.00 & 0.8140 & 2.31 \\
\hline 13.0 & 25.00 & 0.8205 & 2.18 \\
\hline 16.0 & 25.00 & 0.8205 & 2.05 \\
\hline 21.0 & 25.00 & 0.8240 & 1.90 \\
\hline 31.0 & 25.00 & 0.8352 & 1.79 \\
\hline
\end{tabular}


TABLA OF RUN

(basic)

$0.9708 \mathrm{~N}$.

$\mathrm{NaOH}$

$c \cdot c$.

$\left(\mathrm{Fe}\left(\mathrm{NH}_{4}\right)_{3}\left(\mathrm{C}_{6} \mathrm{H}_{5} \mathrm{O}_{7}\right)_{3}\right)$

$c . c$.

E

$\mathrm{pH}$

0.0

24.85

0.6715

4.7

0.5

24.85

0.6715

4.63

1.0

24.85

0.6666

4.7

1.5

24.85

0.6586

4.8

2.0

24.85

0.6465

4.9

2.5

24.85

0.6412

5.0

3.0

24.85

0.6340

$5 \cdot 1$

4.0

24.85

0.6210

5.34

5.0

24.85

0.5947

5.6

6.0

24.85

0.5780

5.9

7.0

24.85

0.5548

6.2

8.0

24.85

0.5174

6.5

9.0

24.85

0.1949

6.8

9.5

24.85

0.4795

6.91

9.9

24.85

0.4571

7.10

11.0

24.85

0.4275

7.40

13.0

24.85

0.3715

8.0

15.0

24.85

0.2890

8.39

17.0

24.85

0.2310

8.60

21.0

24.85

0.1877

8.78

25.0

24.85

0.1354

9.10

30.0

24.85

0.1180 


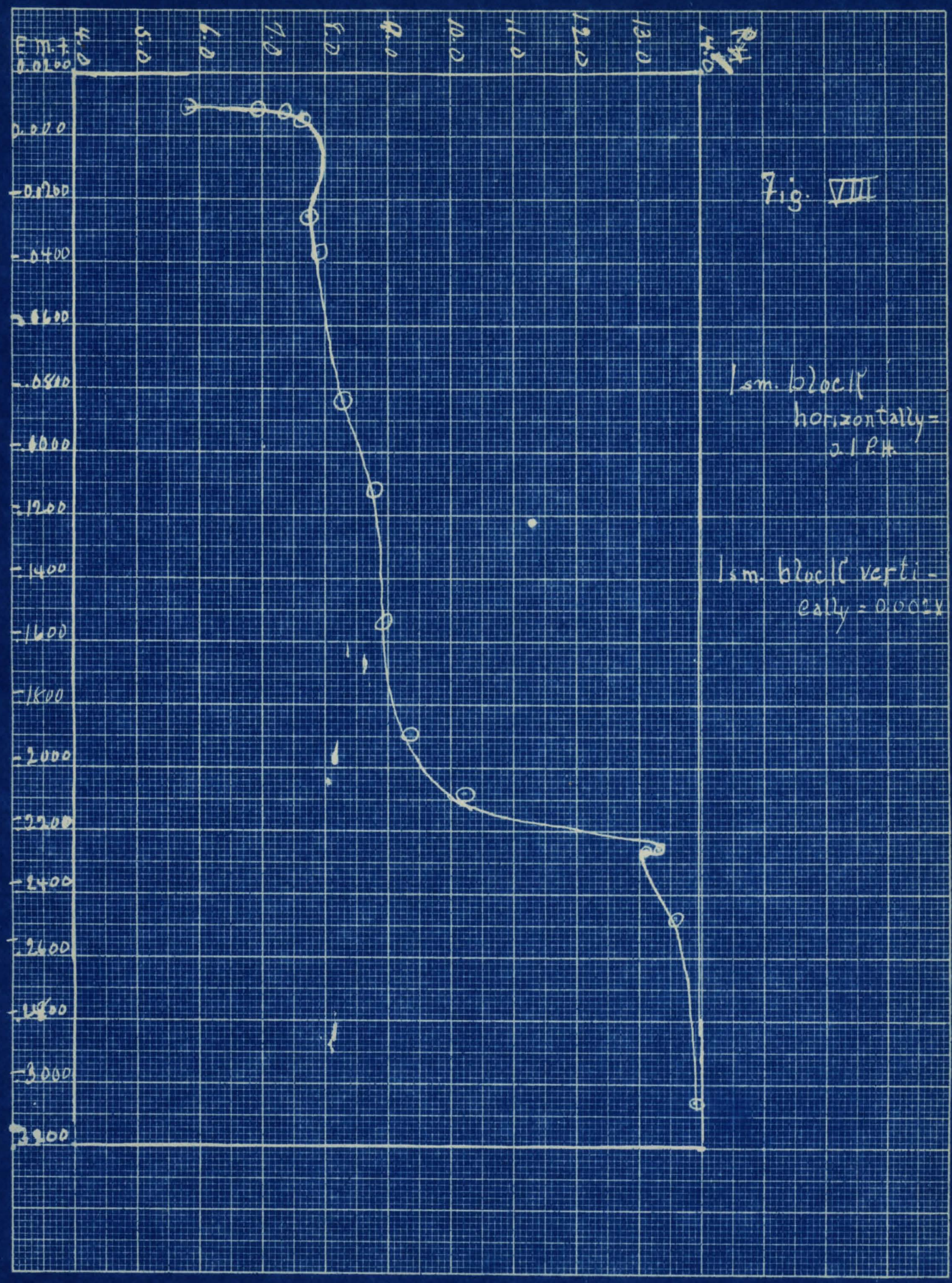




\section{EXPERIMENT NO. 5}

After obtaining a curve upon the effect of pEl on the oxidation potentials of ferric amonium citrate, naturally, the next logical step was to find the effect of pE on the "ferro" rotential. In order to obtain an idea $2 s$ to how it would effect the buffered (oxidation buffer) "ferri-ferro" potential, this solution was also buffered.

As can be seen from the graph, there were two eeparate "breaks" and two leveling off places. From a pH of 5.8 to one of 7.3 , there was little or no change of potentis 1, however, en increase in pil from 7.35 to 9.35 causea a fall in potential of $0.2 \mathrm{v}$. This happens again as an increase of $\mathrm{pH}^{\mathrm{H}}$ from 8.3 to 13.6 only causes a crop in potential of $0.042 \mathrm{v} .$, while an increase of $\mathrm{pH}$ from 13.3 to 13.8 coused $a$ crop of $0.072 \nabla$. This curve also bore out relaticnships ascribed in previous runs.

$$
\begin{aligned}
& \text { TAELE NO. } 5 . \\
& \left(25 \text { c.c. } \mathrm{K}_{2} \mathrm{C}_{2} \mathrm{O}_{4}\right)
\end{aligned}
$$

\section{$0.9708 \mathrm{~N}$. \\ $\mathrm{NaOH}$}

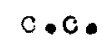

0.0

0.5

1.0

2.5

$0.9708 \mathrm{~N}$

$\mathrm{Ne} \mathrm{OH}$

$c . c$.

$$
\mathrm{Fe}\left(\mathrm{NH}_{4}\right)_{2}\left(\mathrm{SO}_{4}\right)_{2}
$$

$$
\text { c.c. }
$$

50.00

50.00

50.00

50.00

$$
\mathrm{Fe}\left(\mathrm{NH}_{4}\right)_{2}\left(\mathrm{SO}_{4}\right)_{2}
$$$$
c . c \text {. }
$$

$\begin{array}{cl}\mathrm{E} & \mathrm{pH} \\ 0.0095 & 5.8 \\ 0.0093 & 6.91 \\ 0.0093 & 7.35 \\ 0.0050 & 7.60\end{array}$

E. $\quad \mathrm{pH}$ 


$\begin{array}{llll}3.0 & 50.00 & -0.0250 & 7.70 \\ 3.5 & 50.00 & -0.0370 & 7.90 \\ 4.0 & 50.00 & -0.0830 & 8.29 \\ 4.5 & 50.00 & -0.1120 & 8.75 \\ 5.0 & 50.00 & -0.1540 & 8.91 \\ 5.5 & 50.00 & -0.1850 & 9.35 \\ 5.0 & 50.00 & -0.2080 & 10.20 \\ 6.5 & 50.00 & -0.2255 & 13.10 \\ 7.0 & 50.00 & -0.2255 & 13.30 \\ 7.5 & 50.00 & -0.2475 & 13.60 \\ 10.0 & 50.00 & -0.3051 & 13.80\end{array}$




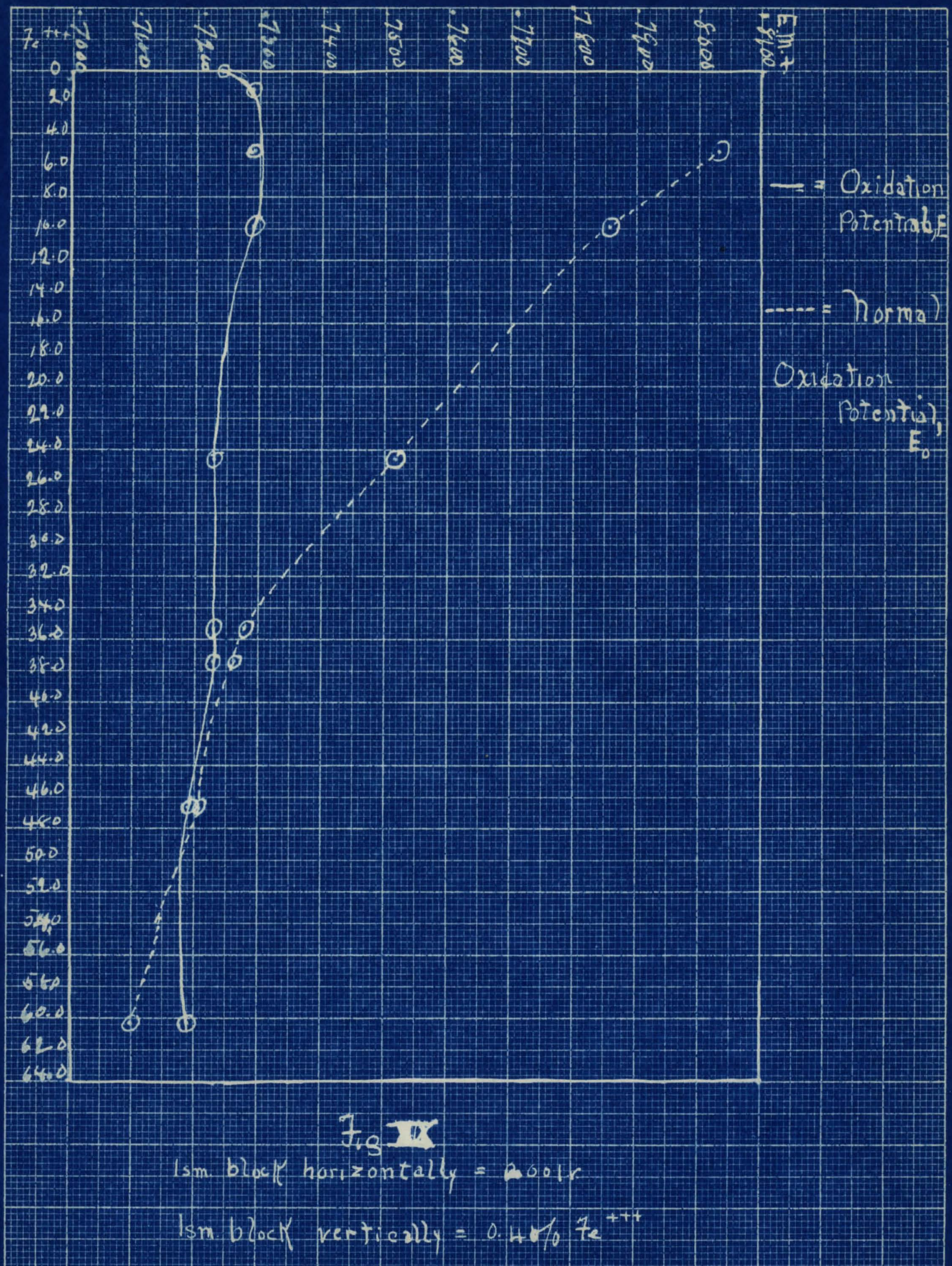


EXPER IMENT NO. 6

In th is graph the potentials of ferric ammonium citrate were lotted aginst those of ferrous ammonium sulphate. From the graph an arr roximate mean of $0.7235 \mathrm{v}$. was derived. This was off a bit from the potential given in the critical table which is 0.7477 . However, as the definite mean of this electrode has not been ascertained and as this research was not with identical ions, this was not considered too $f$ ar off.

TABLE NO. 6

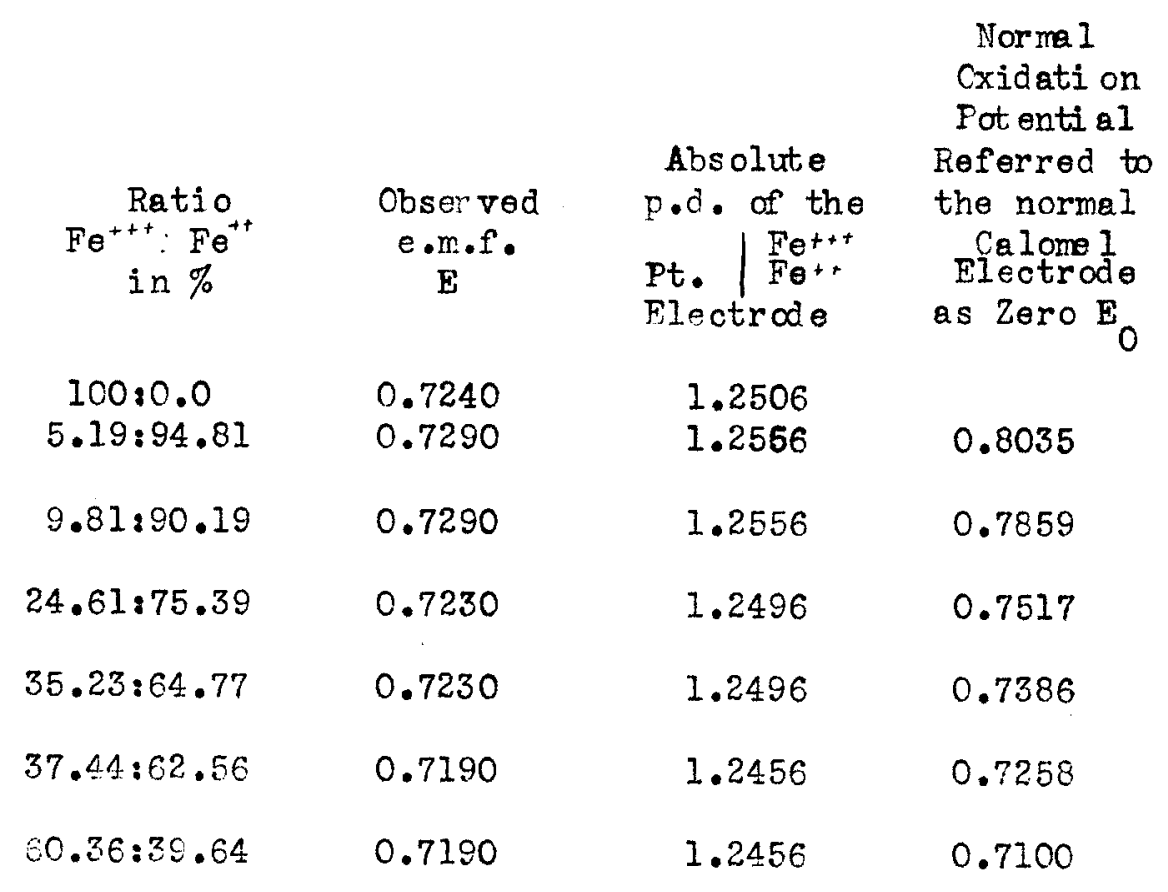




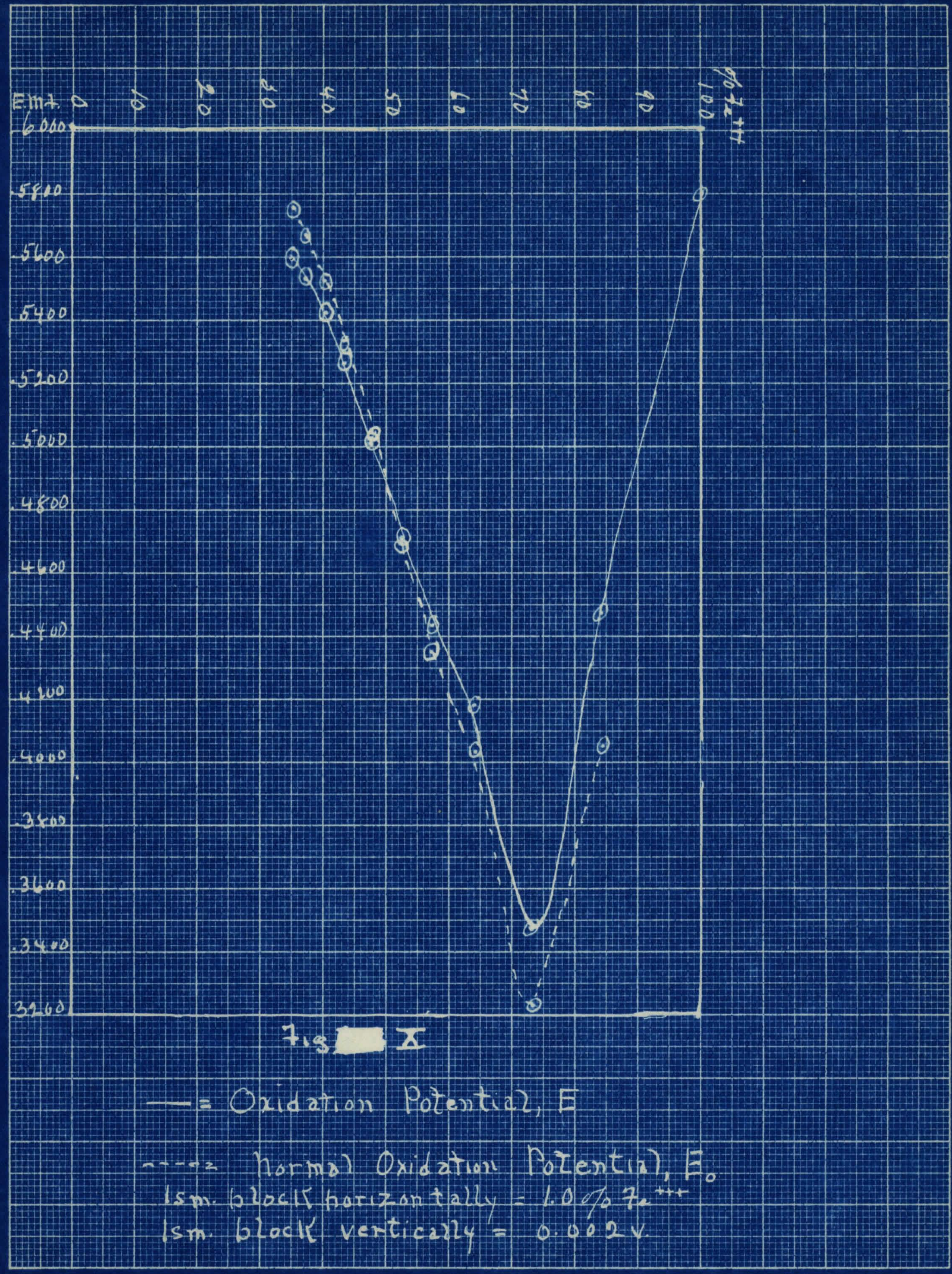




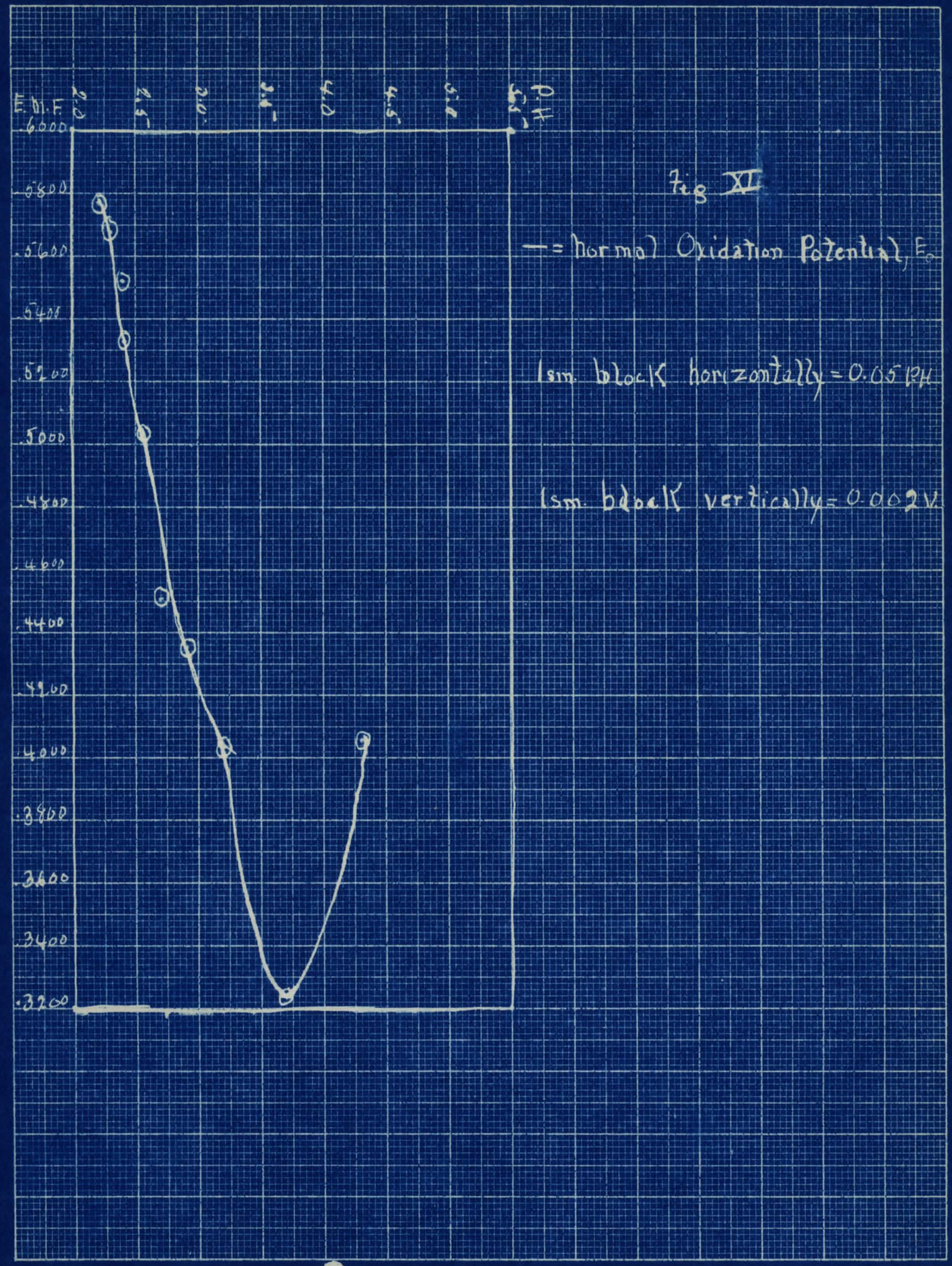




\section{EXPERTMENT NO. 7}

This was the first run in the final form. One milliliters - of N. Fotassium oxalate was used as an oxication buffer. A decided break at the proportion of $73.11 \%$ ferri to $26.89 \%$ ferro was noticed which would seem to indicate that the axidation buffer was ineffectual at this concentration.

Another explanation that might fit this phenomena is that of $T$. J. GIover. Since the ratio $f^{\circ} /$ cxidant $/ f^{r}$ reductant is not equal to the ratio ( $\mathrm{Fe}^{+++} / \mathrm{Fe}^{++}$) ferric ions dived by ferrous work. The E valuesthus obtoined have been termed "apparent" to di stinquish them from the true value as refined by the thermodynamic method. The theory advanced wasthe the ferric and ferrous ions combine with other ions or undisasscciated substences to form complex ferric and ferrous ions, thus forming a new oxidation-reduction system in which the complex ferric ion and the complex ferrous ion form the oxidant and reductant respectively. This system may displace the original ferric-ferrous ion system either partially or (if the complexes formed dissociate to such a slight extent that only a relatively small proportion of ferrous-ferric ion is present) wholly. The emount or composition of these complex ions may vary with the condition of the system, and so the oxidation-reduction notential of the ferrous-ferric mixtures will vary accordingly. 
The mean oxidation potential (normal) derived by approximation was $0.4840 \mathrm{v}$. The plot of the ferri potential agajns those of the ferro cotentials showed a similer curve to that of run No. 5 .

TABLE NO. 7

\begin{tabular}{|c|c|c|c|c|}
\hline $\begin{array}{l}\text { Ratio } \\
\mathrm{Fe}^{+++}: \mathrm{Fe}^{++} \\
\text {in } \%\end{array}$ & $\begin{array}{c}\text { Observod } \\
\text { E.M.F. } \\
\text { E. }\end{array}$ & $\begin{array}{l}\text { Absolute } \\
\mathrm{p} \cdot \mathrm{d} \text {. of the } \\
\text { Pt } \mid \mathrm{Fe}^{+++} \\
\text {Electrode }\end{array}$ & $\begin{array}{l}\text { Normal } \\
\text { Oxidation } \\
\text { Referred to } \\
\text { the Normal } \\
\text { Calome I } \\
\text { Electrode } \\
\text { as Zero, Eo }\end{array}$ & $\mathrm{pF}$ \\
\hline $100.0: 0.0$ & 0.5800 & 1.1066 & & 5.1 \\
\hline $84.47: 15.53$ & 0.4490 & 0.9756 & 0.4056 & 4.3 \\
\hline $73.11: 26.89$ & 0.3485 & 0.8751 & 0.3229 & 3.7 \\
\hline $64.46: 35.54$ & 0.4180 & 0.9446 & 0.4027 & 3.2 \\
\hline $57.62: 42.38$ & 0.4431 & 0.9697 & 0.4352 & 2.91 \\
\hline $52.11: 47.89$ & 0.4715 & 0.9981 & 0.4709 & 2.70 \\
\hline $47.54: 52.46$ & 0.5005 & 1.0271 & 0.5025 & 2.59 \\
\hline $43.71: 56.29$ & 0.5260 & 1.0526 & 0.5326 & 2.48 \\
\hline $40.465: 59.535$ & 0.5422 & 1.0688 & 0.5521 & 2.40 \\
\hline $37.68: 62.32$ & 0.5536 & 1.0802 & 0.5665 & 2.30 \\
\hline $35.23: 64.47$ & 0.5590 & 1.0856 & 0.5752 & 2.25 \\
\hline
\end{tabular}




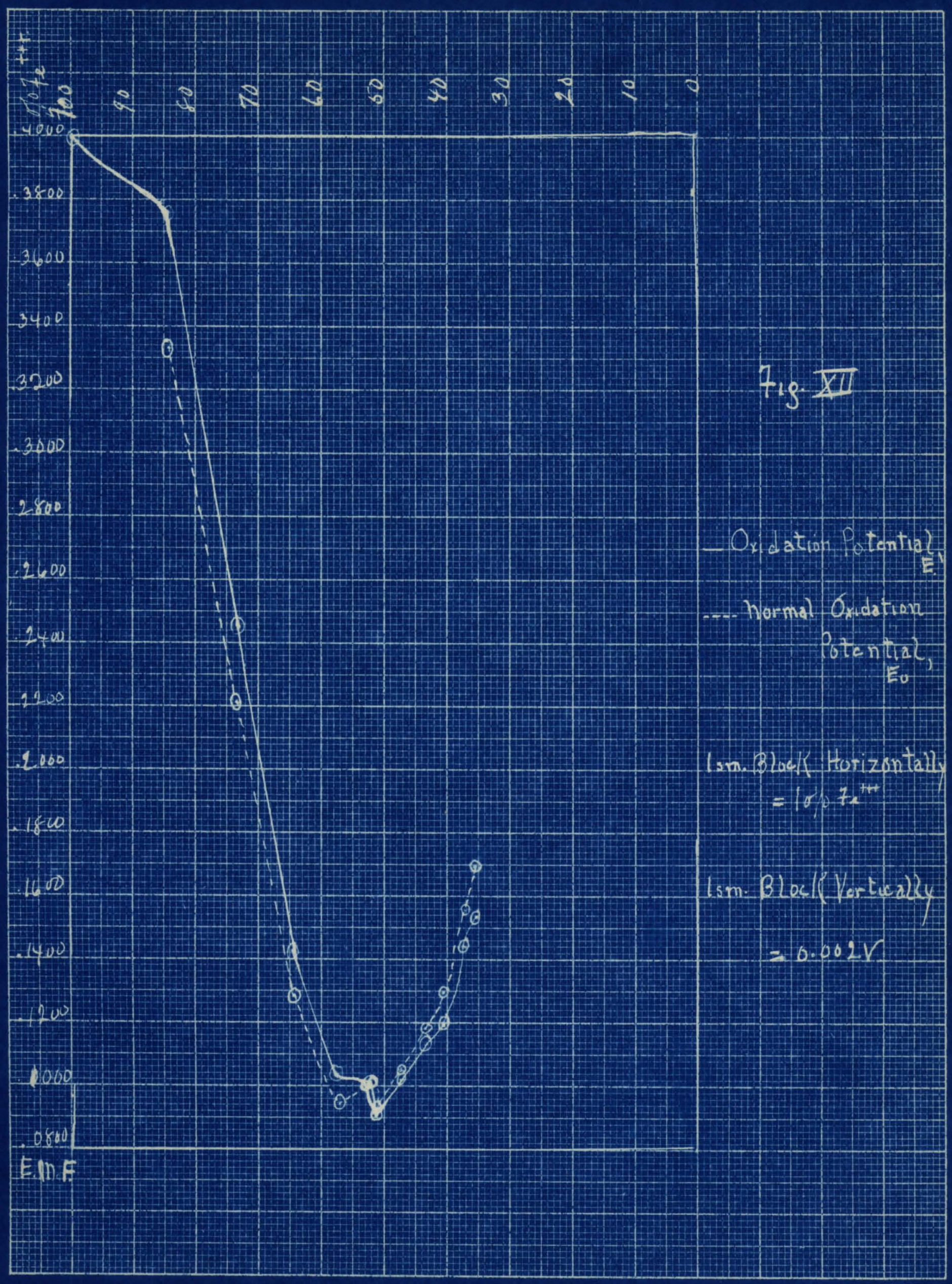




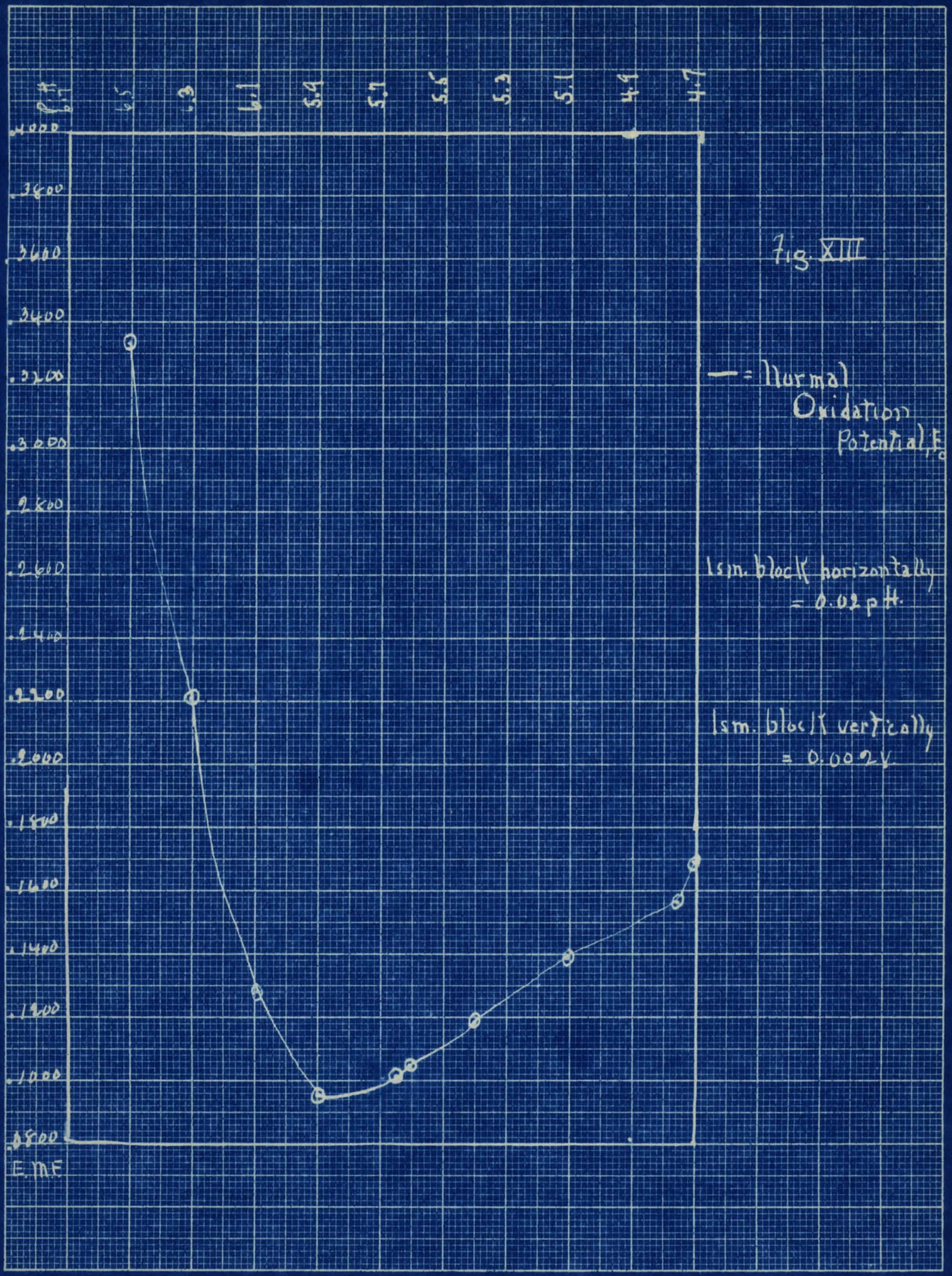


EXPERIMENT NO. 8

In this run the strength of the bufier was increased to 10 milliliters of $N$. potassium oxalate. This increase in the buffer lowered the oxidation potential on an average of about $0.4 \mathrm{v}$. , per reading. This increased buffer action casued the change in cherge to fell back to aproximately even concentration before the potential increased. The mean value of the normal oxidation potential was estimated from the craph to be $0.0920 \mathrm{v}$

It was again noticed that the curve derived from plotting the pH against the normal oxidation potentials follond approximately the same cutline as the preceeding runs.

In order to show how a typical experiment was carried out, the method used is described in dotail at this point.

The electrode was platinized in the usual fashion. The next step was to balance the resistances of the potentiometer aginst the Weston cell until the galvarometer read zero - then the switch was thrown over to the dry cell. The ferric ammonium citrate was added by the calibrated burette into a $250 \mathrm{mil}$.liliters beaker, as was the $N$. potassium oxalate. The burette wes then thoroughly cleaned and fillod with ferrous ammonium sulphate. The beaker containing the ferric ammonium citrate and $N$. potassium oxalate was connected to the calomel cell and the potentiometer by means of anaragar bridge. This bricge was mede by bending a piece of 
ct both onds and filling the tubing with agar-agar which hed been seturated wi th potessium chloride. The number of milliliters of ferrcus amonium sulphate that was desired was run in through the burette. The key of the potentiometer was then closed and a readine made. As a saturated rotassium chlor ice-calcmel cell was used C.246 $\nabla$. was odded to each reading. A pipette would then remove about three mililiters of the soluti on and put it into the glass electrode for a $\mathrm{pH}$ reading. The solution was returned to the original solution after the pH reeding

This method with certain omissions or additions rolated in the experiment described was used throughout the research.

TABIE NO. 8

\begin{tabular}{|c|c|c|c|c|}
\hline $\begin{array}{c}\text { Ratio } \\
\mathrm{Fe}+++\mathrm{Fe}^{++} \\
\text {in } \%\end{array}$ & $\begin{array}{c}\text { Observed } \\
\text { F.M.F. } \\
\text { E }\end{array}$ & $\begin{array}{l}\text { Absclute } \\
\text { D.d. of the } \\
\text { Ft | Fet+t } \\
\text { Electrode }\end{array}$ & $\begin{array}{l}\text { Norma I } \\
\text { Oxidation } \\
\text { referred to } \\
\text { the Normal } \\
\text { Calomel } \\
\text { Electrode } \\
\text { a.s Zero, Eo }\end{array}$ & $\mathrm{pH}$ \\
\hline $100.00: 0.0$ & 0.3995 & $0.926 I$ & * & 6.51 \\
\hline $84.47: 15.53$ & 0.3766 & 0.9032 & 0.3332 & 6.51 \\
\hline $73.11: 26.89$ & 0.2469 & 0.7735 & 0.2213 & 6.30 \\
\hline $64.46: 35.54$ & 0.1436 & 0.6702 & 0.1283 & 5.09 \\
\hline $57.62: 42.38$ & 0.1033 & 0.6290 & 0.0954 & 5.90 \\
\hline $52.11: 47.89$ & 0.1014 & 0.6280 & 0.1008 & 5.68 \\
\hline $51.12: 48.88$ & 0.0209 & 0.6175 & 0.903 & \\
\hline $47.54: 52.46$ & 0.1025 & 0.6291 & 0.1045 & 5.61 \\
\hline $43.71: 56.29$ & 0.1131 & 0.6397 & 0.1196 & 5.30 \\
\hline
\end{tabular}




\begin{tabular}{|c|c|c|c|c|}
\hline \multirow{3}{*}{ 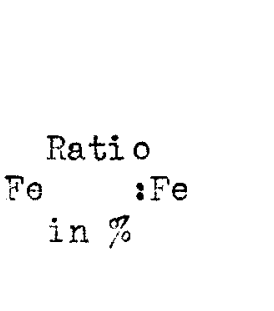 } & \multirow{3}{*}{$\begin{array}{c}\text { Cbserved } \\
\text { E.M.F. } \\
\text { E }\end{array}$} & Absolute & $\begin{array}{l}\text { Normal } \\
\text { oxication } \\
\text { Referred to }\end{array}$ & \multirow{3}{*}{$\mathrm{pH}$} \\
\hline & & $\begin{array}{c}\text { p.d. of the } \\
\text { Pt } \mathrm{Fe} \\
\mathrm{Fe}\end{array}$ & $\begin{array}{l}\text { the Norma } 1 \\
\text { Calome } 1 \\
\text { Electrode }\end{array}$ & \\
\hline & & Electrode & es Zero, $E_{0}$ & \\
\hline $40.465: 59.535$ & 0.1194 & 0.6460 & 0.1293 & 5.11 \\
\hline $37.68: 62.32$ & 0.1440 & 0.6706 & 0.1569 & 4.79 \\
\hline $35.23: 64.77$ & 0.1537 & 0.6803 & 0.1699 & 4.7 \\
\hline
\end{tabular}




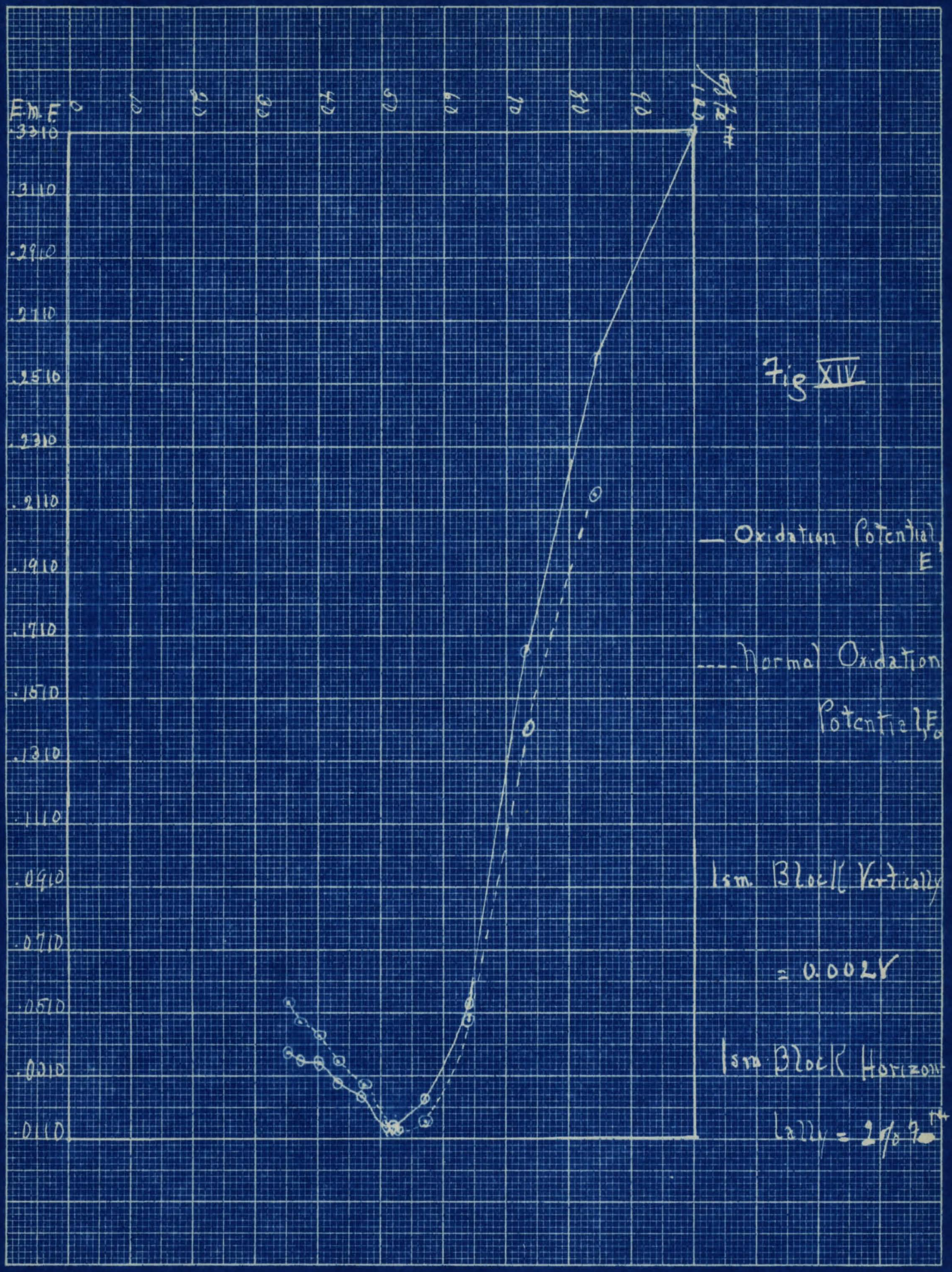




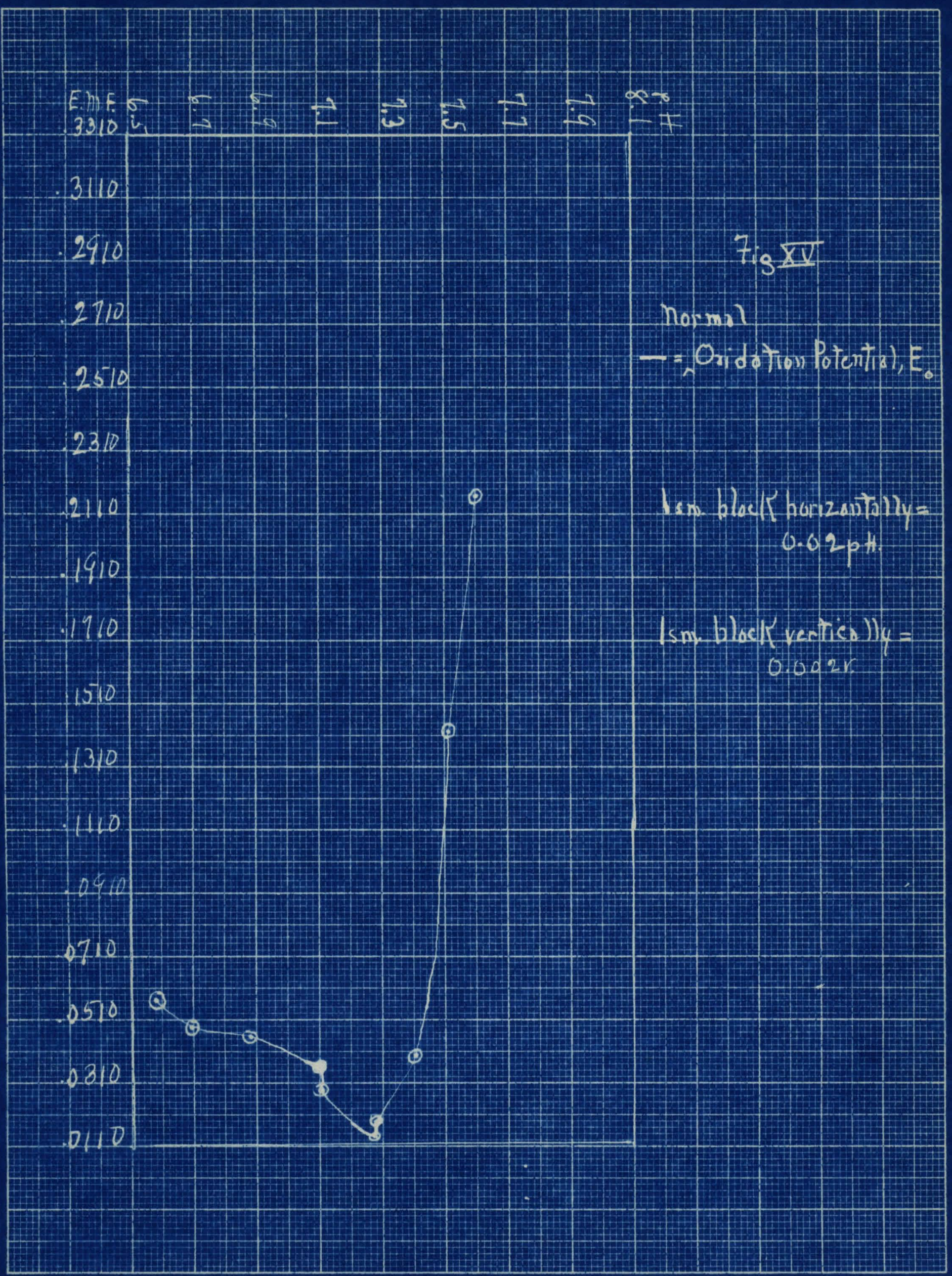




\section{EXPERINFNT NO. 9}

In this run the oxidation buffor was again increased, this time to 25 milliliters of "rotassium oxalate. The oxidation potential fell again, this time but slightly - the average difference ner roadin only varying between $0.08-0.1 \mathrm{Cv}$. The difference in the mean reading was $0.0760 \mathrm{v} \cdot(10 \mathrm{c} \cdot \mathrm{c}$. mean $=$ $0.0920 ; 25 \mathrm{c} \cdot \mathrm{c} \cdot \operatorname{mean}=0.0160 \mathrm{v} \cdot)$

This constant and a more or less steady loss in potential may have been due to a los in the ability of the iron solution to hold hydrogen. This was the theory acivanced by the two French jnvestigators who stated that: "The rotentials of iron derend on the hydrogen it can hold." (24) Thus the addition of the potassium oxalate increased the alkalinity and thus decreased the poiential.

The curve derived from plotting pre aganst normal oxidation otentials followedhe same cutline as that of the one plot ting the percentage of ferric ions against the normal oxidation potentials. 
TABLE NO. 9

\begin{tabular}{|c|c|c|c|c|}
\hline $\begin{array}{c}\text { Ratio } \\
\mathrm{Fe}^{+++}: \mathrm{Fe}^{++} \\
\text {in } \%\end{array}$ & $\begin{array}{c}\text { Observed } \\
\text { E.M.F. } \\
\mathbf{E}\end{array}$ & $\begin{array}{l}\text { Absclute } \\
\text { P.d. of the } \\
\text { Pt / Fet+ } \mathrm{Fe}^{+r} \\
\text { Electrode }\end{array}$ & $\begin{array}{l}\text { Normal } \\
\text { Oxidation } \\
\text { Potential } \\
\text { Referred to } \\
\text { the Normal } \\
\text { Calomel } \\
\text { Electrode } \\
\text { as Zero, Eo }\end{array}$ & $\mathrm{pH}$ \\
\hline $100.00: 0.00$ & 0.3310 & 0.8576 & - & 8.1 \\
\hline $84.47: 15.53$ & 0.2590 & 0.7856 & 0.2156 & 7.8 \\
\hline $73.11: 26.89$ & 0.1672 & 0.6938 & 0.1416 & 7.58 \\
\hline $6.4 .6: 35.54$ & 0.0545 & 0.5811 & 0.0392 & 7.42 \\
\hline $57.62: 42.38$ & 0.0239 & 0.5505 & 0.0160 & 7.29 \\
\hline $52.11: 47.89$ & 0.0150 & $0.5 \Delta 1 \epsilon$ & 0.0141 & 7.29 \\
\hline $51.12: 48.88$ & 0.0145 & 0.5411 & 0.0130 & \\
\hline $47.54: 52.46$ & 0.0265 & 0.5531 & 0.0285 & 7.10 \\
\hline $43.71: 50.29$ & 0.0292 & 0.5558 & 0.0357 & 7.10 \\
\hline $40.465: 59.535$ & 0.0350 & 0.5616 & 0.0449 & 6.89 \\
\hline $37.65: 62.32$ & 0.0351 & 0.5617 & 0.0480 & 8.70 \\
\hline $35.23: 64.27$ & 0.0381 & 0.5647 & 0.0543 & 6.58 \\
\hline
\end{tabular}




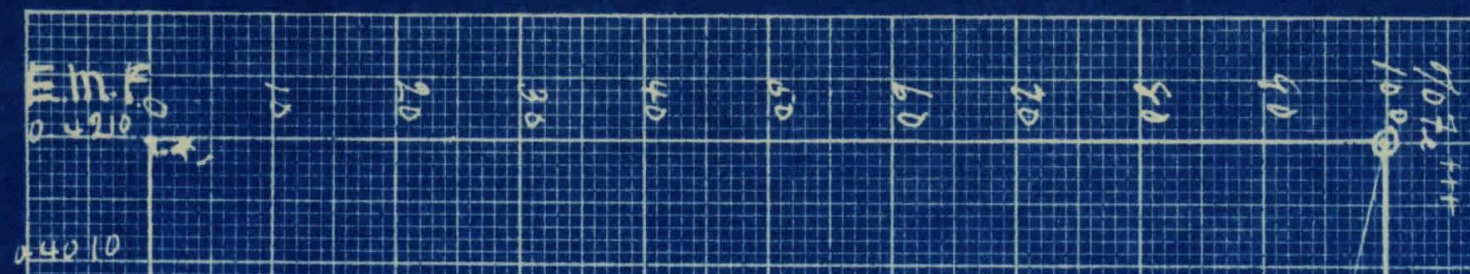

a.jinto

0,3620

0.3410

0.3210

0.3010

$0.28,0$

$0.24,10$

6. 4 in

0.2210

0.2010

\begin{tabular}{|l|}
\hline-1210 \\
\hline 3
\end{tabular}

0.1610

$6=0+10$

0,1410

D. 1010

$\frac{e}{6 .+860}$

$?$

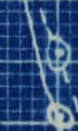

$7 \mathrm{~s}-2$

Sxudation Potantial E -.. Docmar Qidation Potentul, (6) E

sm blocle vestically $=1010$

Ismb)od ( har zontent $=0.002$. 


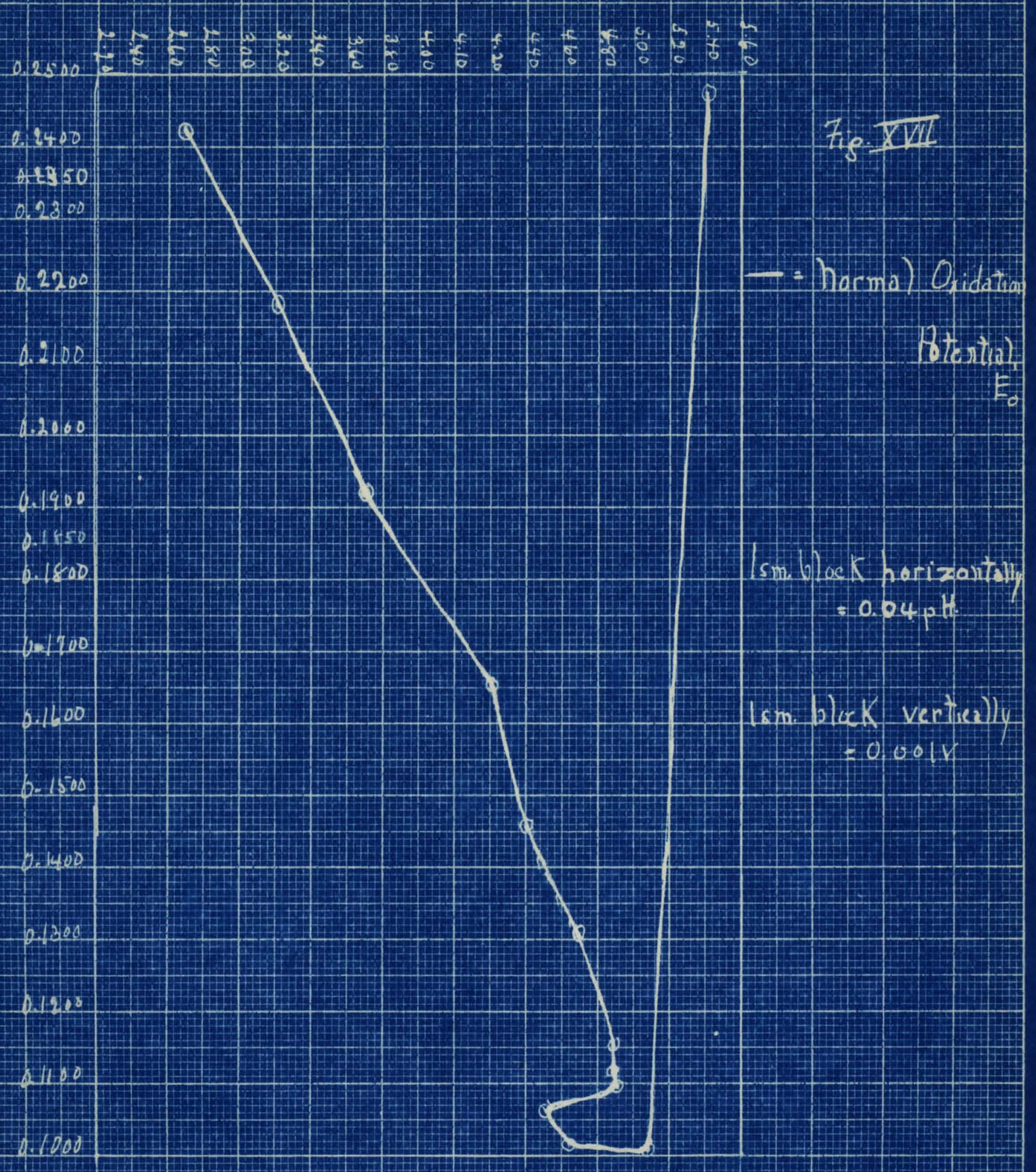


EXFEFITPNT NO. 10

In the next three runs to se ascorived, 10 milliliters of bufer (rotessium oxelete) solution were used with veryine amounts ci ecici.

In experinent 1C, 3 milliliters $c^{2} 0.9642$ V citric acid was used. The curve described from plottinc the rercentage of ferric against the oxidetion otentials clcsely resembled the curve found in that experiment where only on mililiter of buffer was used in the solution. The only difforencewas that the poten 0 is in this experiment were considerably below th ose of the one referred to. The normal oxidation mean of this run computed afproximately from the rrarh was 0.1330 as compared to $0.4840 \mathrm{v}$, of the run where one milliliter of buffer vas used. The curve derived from plott$\therefore$ pr against the normal oxidation potential does not follow e similer attern as the curve plotting oxidation pctential against rercentage of forric ions in solution. Instead it showed "break" toward the alkaline side es the point where according to the rotential readings, the rewes a cecided change in tha oxidation potentials. 
TABIE NO. 10

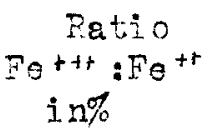

Observed

E.M.

$\mathrm{E}$

Thrm I

Oxidation

Absolute Fotentials p.c. of the Referred to Pt $\mid \mathrm{Fe}^{++r}$ the Norma I $\mathrm{pH}$ Calome 1 Electrode Flectrode as Zero, E。

$\begin{array}{lllll}100.00: 0.00 & 0.4210 & 0.9476 & & 5.48 \\ 84.47: 15.53 & 0.2907 & 0.8473 & 0.2473 & 5.40 \\ 73.11: 26.89 & 0.1260 & 0.6526 & 0.1004 & 5.09 \\ 64.16: 35.54 & 0.1164 & 0.6430 & 0.1011 & 4.65 \\ 62.95: 37.05 & 0.1160 & 0.6426 & 0.1055 & \\ 61.54: 38.46 & 0.1160 & 0.6426 & 0.1066 & 4.51 \\ 60.14: 39.86 & 0.1184 & 0.6450 & 0.1095 & 4.90 \\ 58.87: 41.13 & 0.1211 & 0.6466 & 0.1116 & 4.89 \\ 57.62: 42.38 & 0.1220 & 0.6486 & 0.1151 & 4.89 \\ 52.11: 47.89 & 0.1315 & 0.6581 & 0.1309 & 4.70 \\ 47.54: 52.46 & 0.1433 & 0.6699 & 0.1453 & 4.41 \\ 43.71: 56.29 & 0.1600 & 0.6866 & 0.1665 & 4.21 \\ 40.465: 59.535 & 0.1824 & 0.7090 & 0.1923 & 3.75 \\ 37.23: 64.72 & 0.2366 & 0.7632 & 0.2428 & 2.68\end{array}$




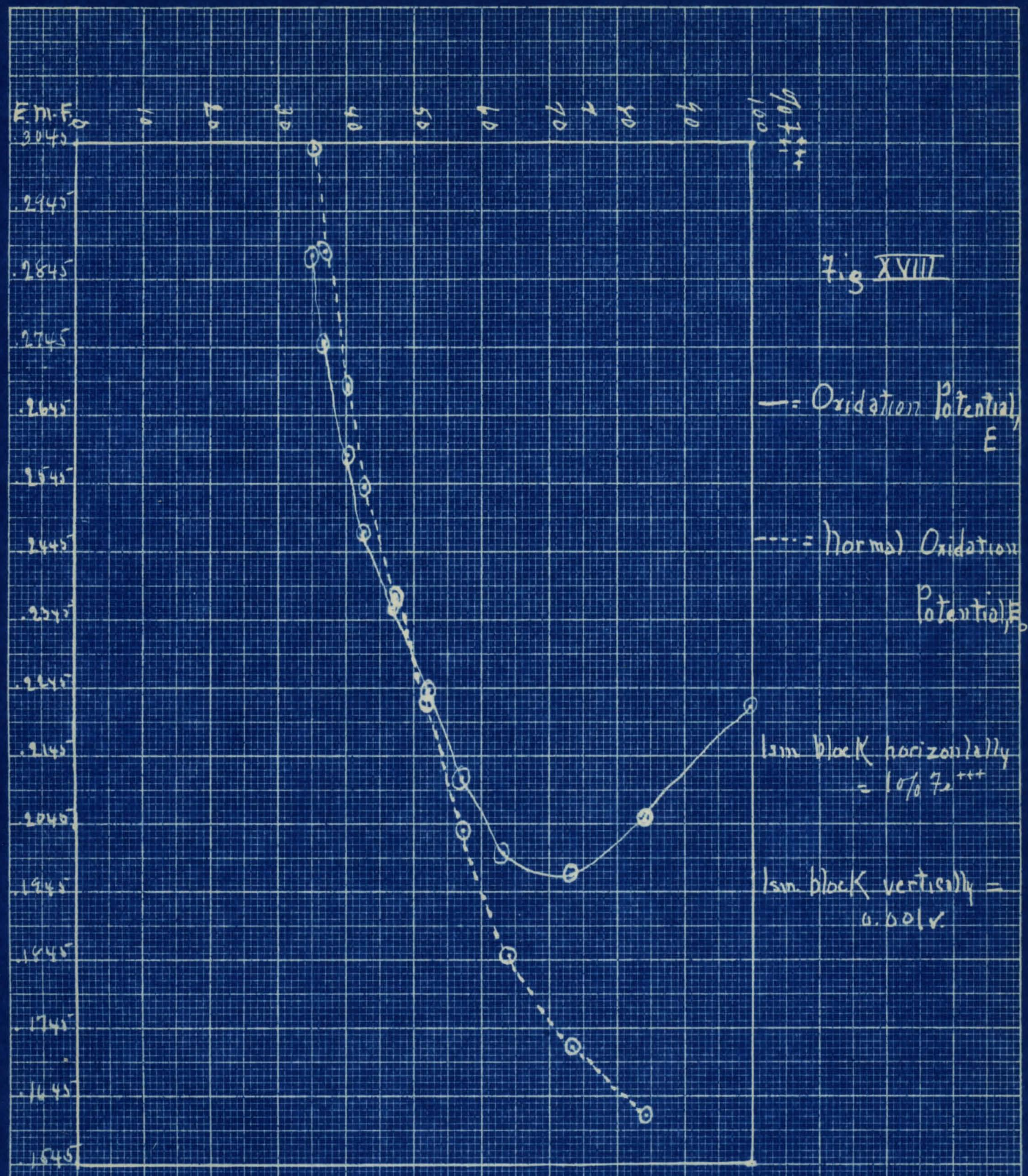




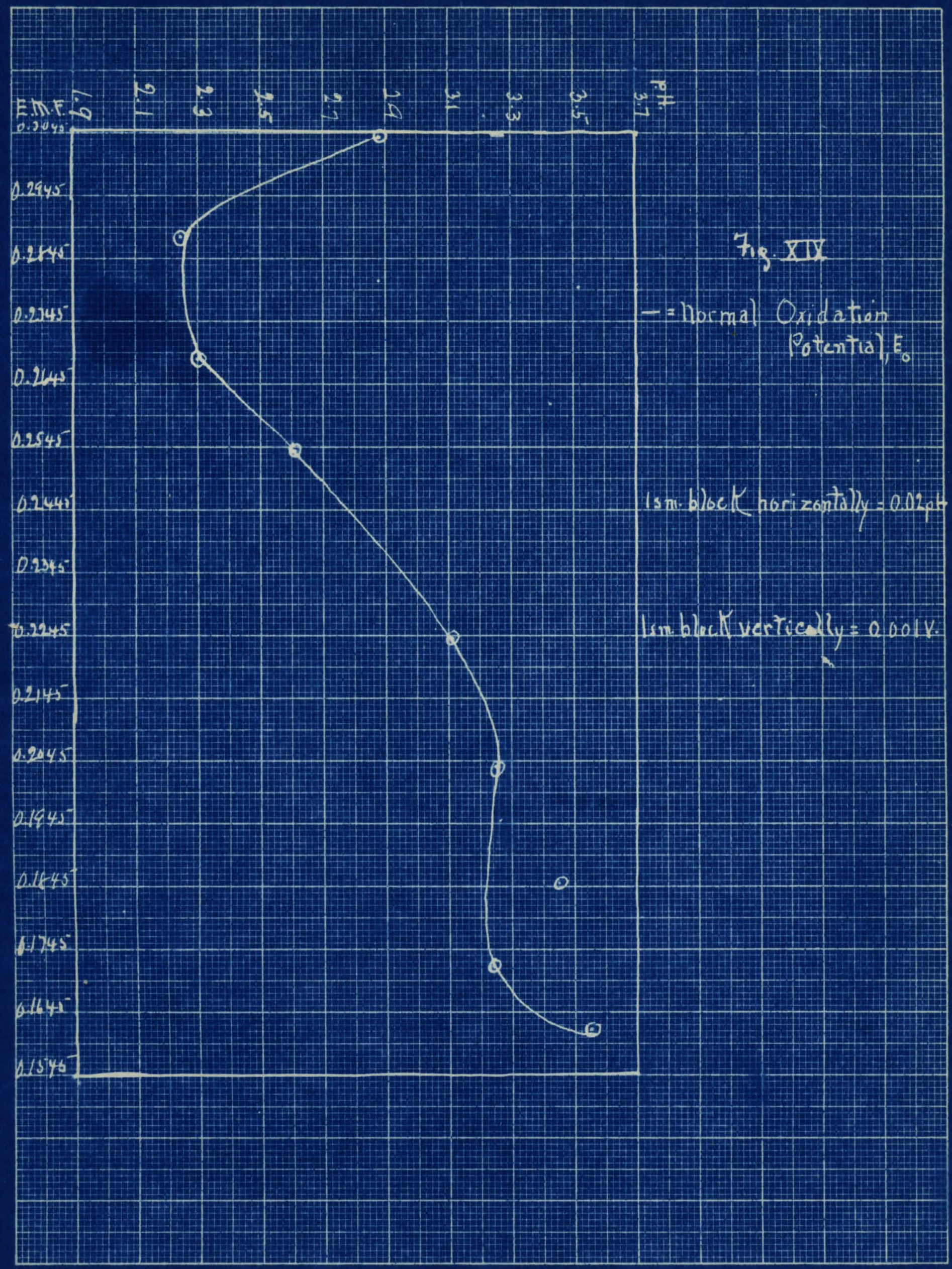


In this run, the amount of acid was increased to 10 milliliters of $0.9642 \mathrm{~N}$. citric cid, the em nunt of buffer used beine costant.

It can be seen that in this grarh an a lmost straight linewas formed by plotting the normal oxidation otential against the rercentage of ferric ions present, while plotting the oxidation fotentials against the percentage of ferrio ions rosent formel a curve.

The mean a idation potential inc reased as compared to the first acid run of this series. It ircreased from $0.1330 \mathrm{v}$. to $0.2295 \mathrm{v}$. , an increase of $0.0965 \mathrm{v}$.

The pH curve agsin described a sirilar one to the one usine 3 miliiliters of the acio andwa totally Cissililar the the oxiation rotential curve. 


\begin{tabular}{|c|c|c|c|c|}
\hline $\begin{array}{l}\text { Ratio } \\
\mathrm{Fe}^{+++}: \mathrm{Fe}^{++} \\
\text {in of }\end{array}$ & $\begin{array}{c}\text { Cbserved } \\
\text { F.M.F. } \\
\text { E }\end{array}$ & 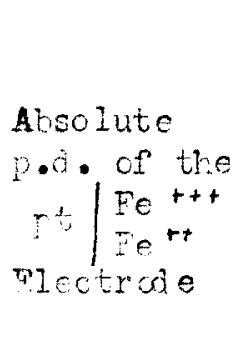 & $\begin{array}{l}\text { Normal } \\
\text { Oxidaticn } \\
\text { Fotertials } \\
\text { Deferied to } \\
\text { the Normal } \\
\text { Calomel } \\
\text { Flectrode } \\
\text { as Zoro, Eo }\end{array}$ & $p H$ \\
\hline $100.00: 0.00$ & 0.2219 & 0.7485 & & 4.00 \\
\hline $84.47: 15.53$ & 0.2050 & 0.7316 & 0.1616 & 3.55 \\
\hline $73.11: 26.89$ & 0.1973 & 0.7239 & 0.1717 & 3.25 \\
\hline $64.46: 35.54$ & 0.2003 & 0.7269 & 0.1850 & 3.45 \\
\hline $57.62: 42.38$ & 0.2114 & 0.7380 & 0.2035 & 8.25 \\
\hline $52.11: 47.89$ & C. 2244 & 0.7510 & C.2238 & 3.11 \\
\hline 47.54 .52 .46 & 0.2360 & 0.7626 & 0.2380 & \\
\hline $43.71: 56.20$ & 0.2474 & 0.7740 & 0.2539 & 2.41 \\
\hline $40.465: 59.535$ & 0.2586 & 0.7852 & 0.2685 & 2.30 \\
\hline $37.68: 62.32$ & 0.2753 & 0.8019 & $0.288 ?$ & 2.25 \\
\hline $35.23: 64.77$ & 0.2880 & 0.8146 & 0.3042 & 2.88 \\
\hline
\end{tabular}




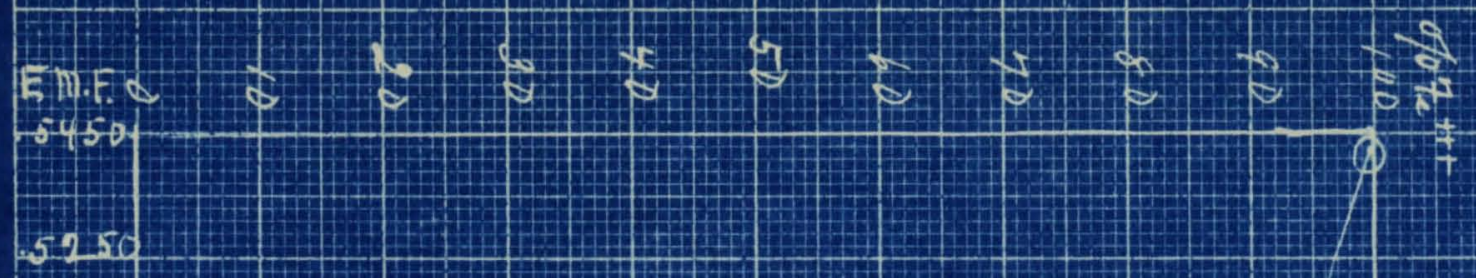

5050

$.486^{\circ}$

.4650

4450

4202

.4050

60

$\Longrightarrow$ Qxidation Pateníne)

E

$3 r 5^{\circ}$

3650

$-3450$

$-3250$

6

$305^{\circ}$

60

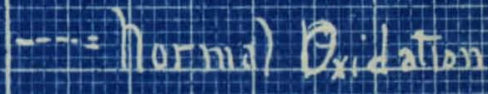

$\operatorname{tg} \frac{x x}{x}$

Potenta) $\frac{\mathrm{E}}{\mathrm{C}}$

\begin{tabular}{|l|}
\hline 2850 \\
\hline 2650 \\
\hline 2450 \\
\hline
\end{tabular}

Q 5

Icm bloct (harizox)o)

$=1007+t$ Q2
$Q$

$\sin (b)(x)(y \cos i 2 a))$

$=0.002 \mathrm{t}$

2250 


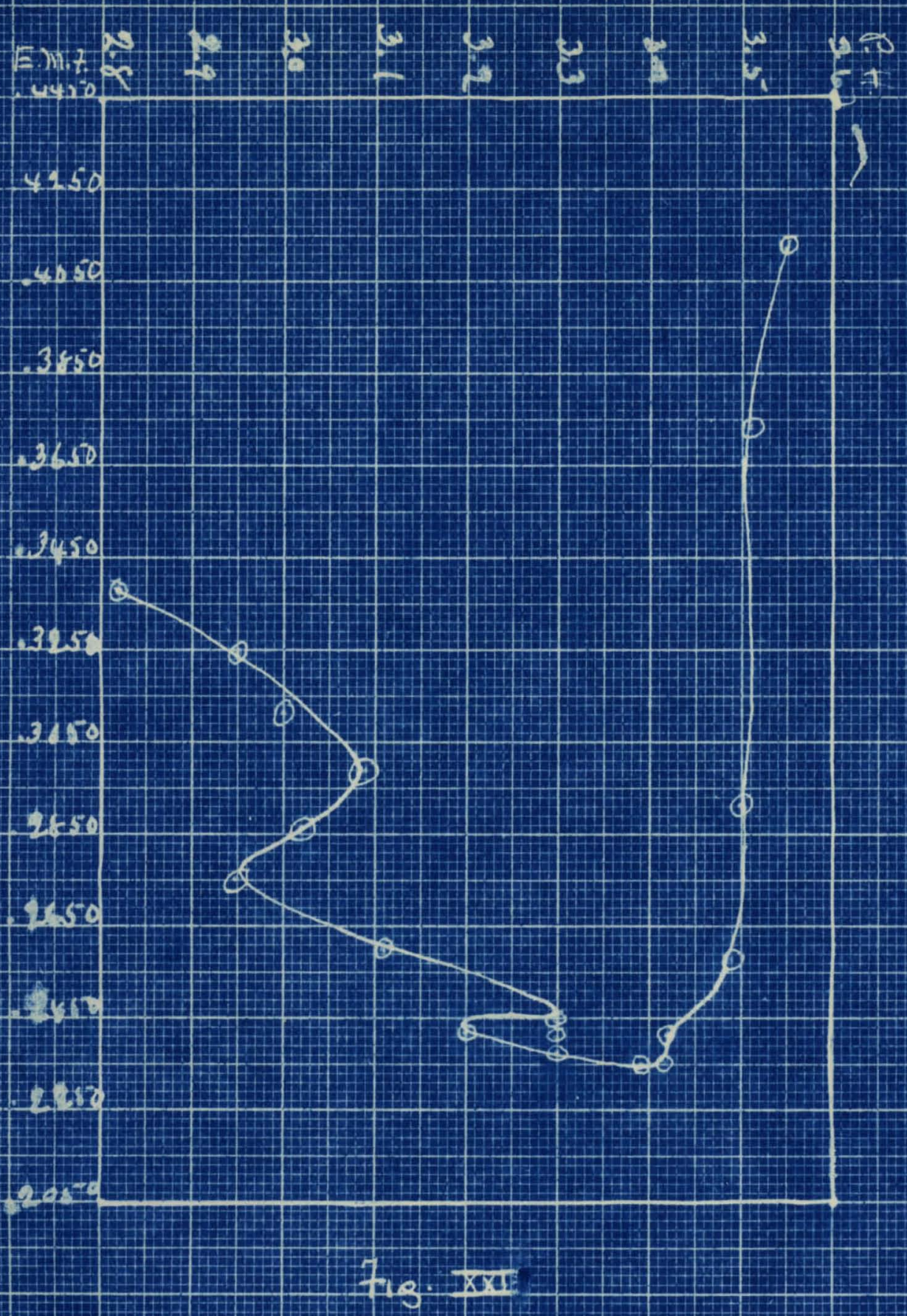

- ahormal Oxidation Potential, Eo Ism. blac I' horzzontally $=0.01 \mathrm{PH}$ $\sin$ block verticalty $=6.002 v$ 


\section{EXPERIMEN NO. 12}

In this run $22 \mathrm{milliliters}$ of $0.9642 \%$ civric acid were used with 10 milliliters of the bufier. Araj the mean oxidation potential mas computed ono found to have boen raised, this time to $0.2790 \mathrm{v}$. This gave us an incease in potential of about $0.0495 \mathrm{v}$. for the auitionel 12 milliliters of acic. Thus it seemed to indjoate that the higher the acicity of the solution tended to increase uhe cyidation rotentiels. This wes indic gt ed in the earljer runs when jt vas pointed at that the retentials of both ferrous amronium sulphate and forric amonium citrate increased with a fail in fil and decreased wi. th a rise in pH. Also the French investigators mentioned earlier found that the potentials of an iron solution increased with a fall in pH and fell with a rise in $\mathrm{pH}$. (24) Howe ver, other investigators working without buffers found that the oxidation potentials fell with increasing concentration of acid, and on plotting, the ralues of the potentials we re seen to decrease linearly with the normality of the hycrochloric acid for concontration betweon $1.0 \%$ and $10.0 \%$. The total change involved was considerable. However, it was ficund that there was a definite variation of efrect by acia on different compounds. (2) Through the finding from this work it could te said thet when a bufferwas used with ferric amonium citrate, inc reased acidity, increased the oxidation ptentials of the comound.

The Eraph of theourve of the normal oxidation potontial agains the pH showed ractically the samie type co curve that the two previous figures show. 
TABLE NO. 12

\begin{tabular}{|c|c|c|c|c|}
\hline $\begin{array}{l}\text { Ratio } \\
\mathrm{Fe}: \mathrm{F} \theta \\
\text { in } \%\end{array}$ & $\begin{array}{c}\text { Observed } \\
\text { E.T.F. } \\
\text { E. }\end{array}$ & $\begin{array}{l}\text { Absolute } \\
\text { p.d. of the } \\
\text { Pt Fe } \\
\text { Electrode }\end{array}$ & $\begin{array}{l}\text { Feferred to } \\
\text { the Normal } \\
\text { Calone } 1 \\
\text { Electrode } \\
\text { as Zero, Eo }\end{array}$ & $\mathrm{pH}$ \\
\hline $100.00: 0.00$ & 0.542 .3 & 1.0689 & & 3.55 \\
\hline $84.47: 15.53$ & 0.4555 & 0.9821 & 0.4121 & 3.55 \\
\hline $81.93: 18.07$ & 0.4129 & 0.9395 & 0.3742 & 3.51 \\
\hline $79.53: 20.47$ & 0.3252 & 0.8918 & 0.2910 & 3.50 \\
\hline $77.25: 22.75$ & 0.2895 & 0.8157 & 0.2582 & 3.49 \\
\hline $75.15: 24.85$ & 0.2690 & 0.7956 & 0.2417 & 3.42 \\
\hline $73.11: 26.89$ & 0.2610 & 0.7855 & 0.2351 & 3.42 \\
\hline $71.20: 28.80$ & C. 2589 & 0.7855 & 0.2351 & 3.39 \\
\hline $69.39: 30.61$ & 0.2589 & 0.7855 & 0.2379 & 3.30 \\
\hline $67.69: 32.31$ & 0.2589 & 0.7855 & 0.2388 & 3.30 \\
\hline $65.03: 33.97$ & 0.2591 & 0.7857 & 0.2421 & 3.20 \\
\hline $64.46: 35.54$ & 0.2602 & 0.7868 & 0.2449 & 3.30 \\
\hline $57.62: 42.38$ & 0.2671 & 0.7537 & 0.2592 & 3.11 \\
\hline $52.11: 47.89$ & 0.2756 & 0.8022 & 0.2750 & 2.95 \\
\hline $47.54: 52.46$ & 0.2836 & 0.8102 & 0.2856 & $3 . \infty$ \\
\hline $43.71: 56.29$ & 0.2925 & 0.8191 & 0.2900 & 3.08 \\
\hline $40.465: 59.535$ & 50.3016 & 0.8282 & 0.3115 & 3.00 \\
\hline $37.68: 62.32$ & 0.3113 & 0.8379 & 0.3242 & 2.95 \\
\hline $35.23: 64.77$ & 0.3210 & 0.8476 & 0.3372 & 2.82 \\
\hline
\end{tabular}

Normal

Oxidation

Fotential

Referred $t$

the Normal

Calorie 1

lectrode

3.55

3.55

3.51

3.50

3.49

3.42

3.42

3.39

3.30

3.30

3.20

3.30

3.11

.95

$3 . \infty$

3.08

3.00

2.95

2.82 


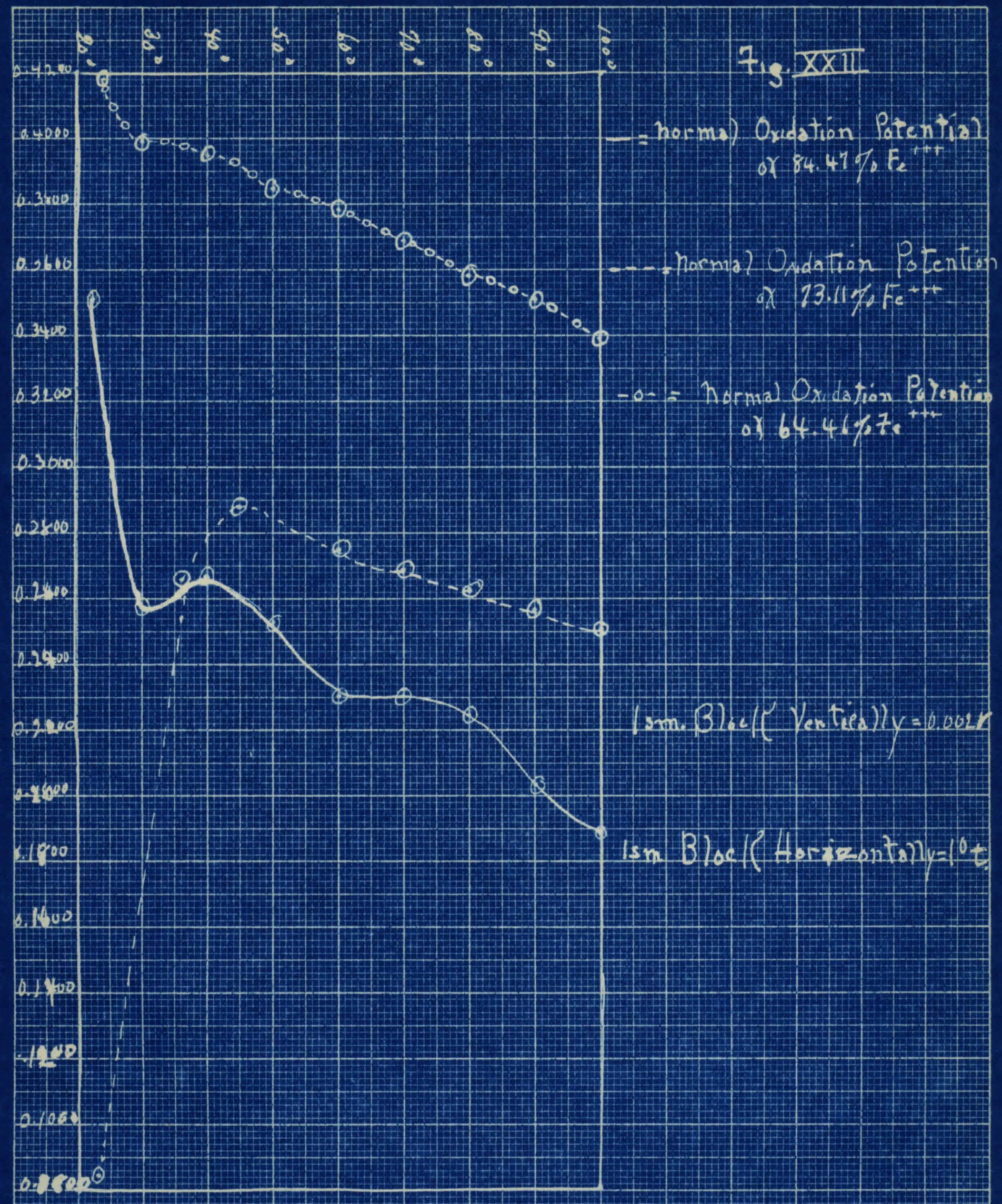




\section{EXPERTMEITS NOS. 13-14-15}

The next series of runs were made to determine the offects of temrereture on various concentrations of the "ferrousferic" electroie.

The ffrst concentration run was $84.47 \%$ ferri: $15.53 \%$

ferro. The potentials in this run fell thragh out except during the portion wher s the temperature of the solution was between $30^{\circ}$ and $40^{\circ}$ when the potentials rose sightly.

The second concentration run was $73.11 \%$ ferri: $26.89 \%$

ferro. The potentiels of this solution upon heating rose abruptly until a temperature of $45^{\circ}$ was reached, the potentials the reafter gradually fell upon increased rise in temperature.

The third and last concentration run was $64.46 \%$ ferri: $35.54 \%$ ferro. The potentials of this solution fell constently as heat was applied.

The $\mathrm{pH}$ of the three solutions were resnoctively 4.3 , 3.7, and 3.2. As can be seen either from the Eraph or from the chart, the potentials fell upon heating, and the lower the DH the higher the potential. One investigator vorking with unbuffered soluti cns found exactly the opposite upon heating. These men found: (1) an increment in potential wi th increase in temeraturs; (2) increment diminishes with increasing acid concentration: (3) mixtures containing a much larger proportion of ferric than ferrous (chloride) have potentiels raised by temperature at al 1 acid concentrations:(4) in miztures containing high proportions of ferrous chloride the effect of temrerature was to raise potentiel in low acid concentration and depress at high. (3) 
TABLE NO. 13

\begin{tabular}{|c|c|c|c|c|}
\hline $\begin{array}{c}\text { Ratio } \\
\mathrm{Fe}^{+++}: \mathrm{Fe}^{++} \\
\text {in } \%\end{array}$ & $\begin{array}{c}\text { Observed } \\
\text { E.M.F. } \\
\text { E. }\end{array}$ & 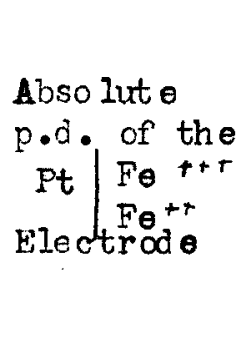 & $\begin{array}{l}\text { Normal } \\
\text { Oxidation } \\
\text { Potential } \\
\text { Referred to } \\
\text { the Normal } \\
\text { Calome } 1 \\
\text { Electrode } \\
\text { as Zero, Eo }\end{array}$ & Temp. \\
\hline $84.47: 15.53$ & 0.3940 & 0.9206 & 0.3506 & $22.5^{\circ}$ \\
\hline $84.47: 15.53$ & 0.3010 & 0.8276 & 0.2576 & $30.0^{\circ}$ \\
\hline $84.47: 15.53$ & 0.3096 & 0.8362 & 0.2662 & $40.0^{\circ}$ \\
\hline $84.47: 15.53$ & 0.2960 & 0.8266 & 0.2526 & $50.0^{\circ}$ \\
\hline $84.47: 15.53$ & 0.2735 & 0.8001 & 0.2301 & $60.0^{\circ}$ \\
\hline $84.47: 15.53$ & 0.2735 & 0.8001 & 0.2301 & $70.0^{\circ}$ \\
\hline $84.47: 15.53$ & 0.2681 & 0.7947 & 0.2247 & $80.0^{\circ}$ \\
\hline $84.47: 15.53$ & 0.2461 & 0.7726 & 0.2026 & $90.0^{\circ}$ \\
\hline $84.47: 15.53$ & 0.2328 & 0.7595 & 0.1895 & $100.0^{\circ}$ \\
\hline
\end{tabular}

TABLE NO. 14

$\begin{array}{lllll}73.11: 26.89 & 0.1110 & 0.6376 & 0.0854 & 23.0^{\circ} \\ 73.11: 26.89 & 0.2900 & 0.8166 & 0.2644 & 36.0^{\circ} \\ 73.11: 26.89 & 0.3130 & 0.8396 & 0.2874 & 45.0^{\circ} \\ 73.11: 26.89 & 0.3013 & 0.8279 & 0.2757 & 60.0^{\circ} \\ 73.11: 26.89 & 0.2945 & 0.8211 & 0.2689 & 70.0^{\circ} \\ 73.11: 26.89 & 0.2878 & 0.8144 & 0.2622 & 80.0^{\circ} \\ 73.11: 26.89 & 0.2828 & 0.8094 & 0.2572 & 90.0^{\circ} \\ 73.11: 26.89 & 0.2773 & 0.8039 & 0.2517 & 100.0^{\circ}\end{array}$


TABLE NO. 15

\begin{tabular}{|c|c|c|c|c|}
\hline $\begin{array}{l}\text { Ratio } \\
\mathrm{Fe}^{+++}: \mathrm{Fe}^{+t} \\
\text { in } \%\end{array}$ & $\begin{array}{c}\text { Obser ved } \\
\text { E.M.F. } \\
\text { E }\end{array}$ & $\begin{array}{l}\text { Absolute } \\
\text { p.d. of the } \\
\text { Pt. } \mathrm{Fe}^{++t} \\
\text { Electrode }\end{array}$ & $\begin{array}{l}\text { Normal } \\
\text { Oxidation } \\
\text { Fotential } \\
\text { Referred to } \\
\text { the Normal } \\
\text { Calone } 1 \\
\text { Electrode } \\
\text { as Zero, } \mathrm{B}_{0}\end{array}$ & Temp. \\
\hline $64.46: 35.54$ & 0.4335 & 0.9601 & 0.4182 & $24.0^{\circ}$ \\
\hline $64.46: 35.54$ & 0.4149 & 0.9415 & 0.3996 & $30.0^{\circ}$ \\
\hline $64.46: 35.54$ & 0.4100 & 0.9366 & 0.3847 & $40.0^{\circ}$ \\
\hline $64.46: 35.54$ & 0.4012 & 0.9278 & 0.3859 & $50.0^{\circ}$ \\
\hline $64.46: 35.54$ & 0.3936 & 0.9102 & 0.3783 & $60.0^{\circ}$ \\
\hline $64.46: 35.54$ & 0.3846 & 0.9012 & 0.3693 & $70.0^{\circ}$ \\
\hline $64.46: 35.54$ & 0.3735 & 0.8991 & 0.3582 & $80.0^{\circ}$ \\
\hline $64.46: 35.54$ & 0.3665 & 0.8921 & 0.3512 & $90.0^{\circ}$ \\
\hline $64.46: 35.54$ & 0.3536 & 0.8802 & 0.3393 & $100.0^{\circ}$ \\
\hline
\end{tabular}




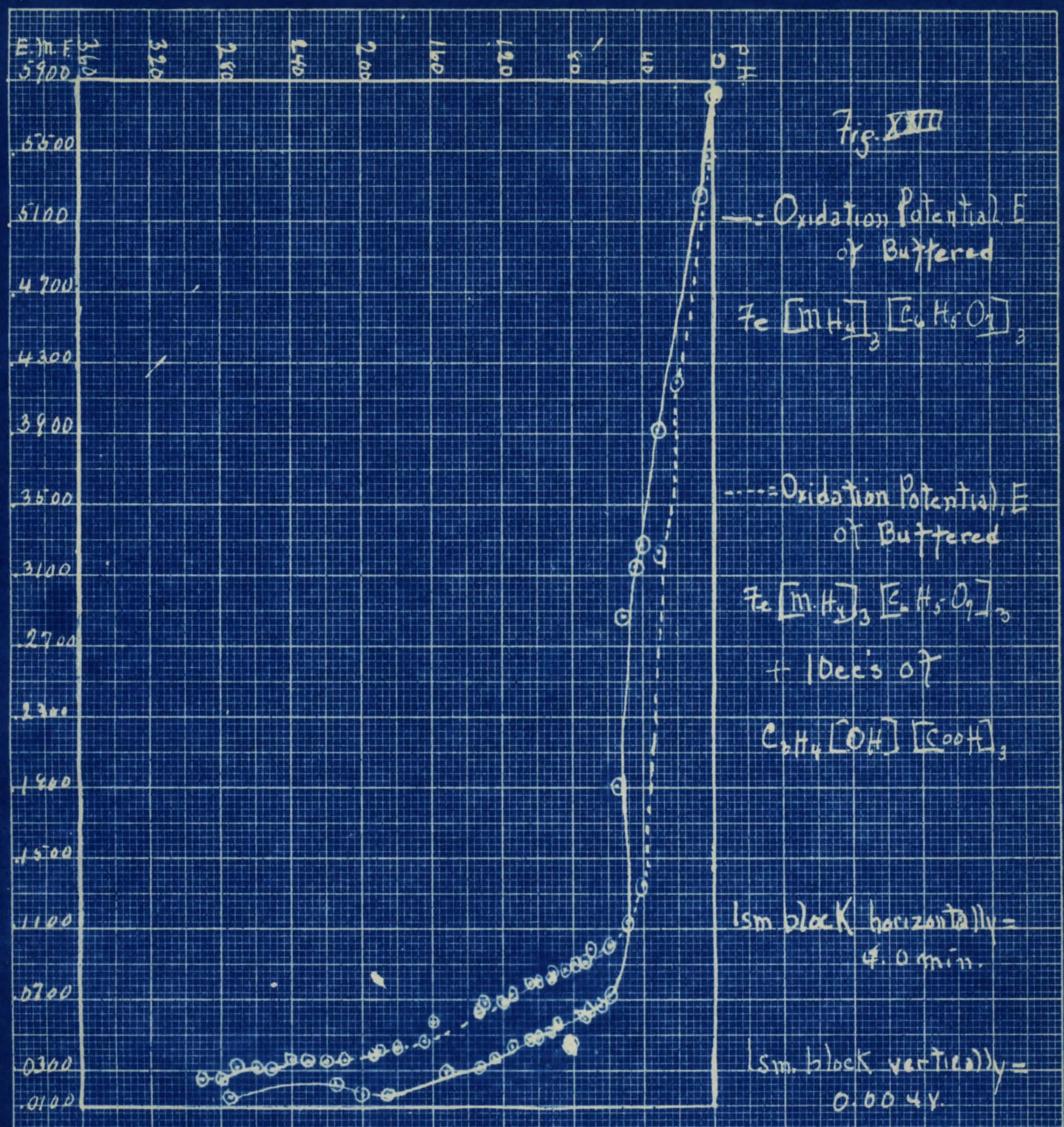


EXPERIYTNS NOS. 16 \& 17

Thsse runs were made for qualitative purposes. There was no attempt made to standardize the light source used. The tyre of light source used was a mercury-vapor one. This lamp is put out by the General Electric/and goes under the name General Electric Arc. The light sou rcewis derived from the mercury which was ionized under pressure and electricity shot through it.

We notice from a glance at the Eraphs that the solution containing the citric acid started "breaking" a bit before the other one. Both solutions contained 5 milliliters of ferric armonium citrate and 10 milliliters of potassium oxalate. The solutions turned a dark brown after the break in potential.

TABLE NO. 16

$5 \mathrm{c} . \mathrm{c}$.' 's of $\mathrm{Fe}\left(\mathrm{NH}_{4}\right)_{3}\left(\mathrm{C}_{6} \mathrm{H}_{5} \mathrm{O}_{7}\right)_{3}$

$10 \mathrm{c.c}$.' 's of $\mathrm{K}_{2} \mathrm{C}_{2} \mathrm{O}_{4}$

General Electric Arc

$\begin{array}{ccc}\text { Time (minutes) } & \mathbf{E} & \mathrm{pH} \\ 0 & 0.5815 & 5.5 \\ 5 & 0.5260 & \\ 30 & 0.3922 & 5.3 \\ 40 & 0.3271 & 5.98 \\ 45 & 0.3144 & 6.1 \\ 50 & 0.2899 & 6.3 \\ 55 & 0.1919 & 6.38 \\ 60 & 0.0731 & 6.30 \\ 65 & 0.0665 & 6.12\end{array}$


TABLF No. $16\left(\operatorname{con}^{\prime} t\right)$

\begin{tabular}{|c|c|c|c|}
\hline Tims & Cminutes & $\mathbf{E}$ & $\mathrm{pH}$ \\
\hline 70 & & 0.0636 & 6.25 \\
\hline 75 & & 0.0585 & 5.92 \\
\hline 80 & & 0.0440 & 5.68 \\
\hline 85 & & 0.0434 & 4.68 \\
\hline 90 & & 0.0575 & 5.35 \\
\hline 95 & & 0.0505 & 5.25 \\
\hline 100 & & 0.0492 & 5.95 \\
\hline 105 & & 0.0491 & 5.89 \\
\hline 115 & & .0 .0445 & 6.10 \\
\hline 125 & & 0.0365 & 6.10 \\
\hline 135 & & 0.0321 & 4.38 \\
\hline 155 & & 0.0280 & 3.34 \\
\hline 185 & & 0.0150 & 4.26 \\
\hline 200 & & 0.0176 & 5.10 \\
\hline 215 & & 0.0226 & 5.52 \\
\hline 275 & & 0.0144 & 6.21 \\
\hline \multicolumn{4}{|c|}{$\begin{array}{l}\text { TABLE NO. } 17 \\
5 \mathrm{c} \cdot \mathrm{c} \text {.' 's of } \mathrm{Fe}\left(\mathrm{NH}_{4}\right)_{3}\left(\mathrm{C}_{6} \mathrm{H}_{5} \mathrm{O}_{7}\right)_{3} \\
10 \mathrm{c} \cdot \mathrm{c} \text {.' 's of } \mathrm{K}_{2} \mathrm{C}_{2} \mathrm{O}_{4} \\
10 \mathrm{c} \cdot \mathrm{c} \text {. 's of } \mathrm{C}_{3} \mathrm{H}_{4}(\mathrm{OH})(\mathrm{COOH})_{3}\end{array}$} \\
\hline Time & (minutes) & $\mathrm{E}$ & $\mathrm{nH}$ \\
\hline 0 & & 0.5848 & 0.90 \\
\hline 10 & & 0.5490 & \\
\hline 20 & & 0.4210 & \\
\hline 30 & & 0.3270 & \\
\hline 40 & & 0.1346 & \\
\hline
\end{tabular}


TABLE NO. 17 (con't)

\begin{tabular}{|c|c|}
\hline Time (mi nutes) & $\mathrm{E}$ \\
\hline 50 & 0.1110 \\
\hline 60 & 0.1027 \\
\hline 70 & 0.0964 \\
\hline 75 & 0.0924 \\
\hline 80 & 0.0904 \\
\hline 85 & 0.0873 \\
\hline 90 & 0.0850 \\
\hline 95 & 0.0835 \\
\hline 100 & 0.0818 \\
\hline 105 & 0.0786 \\
\hline 115 & 0.0731 \\
\hline 120 & 0.0691 \\
\hline 130 & 0.0680 \\
\hline 135 & 0.0630 \\
\hline 160 & 0.0580 \\
\hline 165 & 0.0470 \\
\hline 180 & 0.0424 \\
\hline 190 & 0.0419 \\
\hline 195 & 0.0384 \\
\hline 210 & 0.0350 \\
\hline 220 & 0.0344 \\
\hline 230 & 0.0341 \\
\hline 240 & 0.0341 \\
\hline 250 & 0.0305 \\
\hline 260 & 0.0305 \\
\hline 270 & 0.0301 \\
\hline
\end{tabular}


TABLE NO. $17\left(\mathrm{con} \mathrm{o}^{\prime} \mathrm{t}\right)$

$\begin{array}{ccc}\text { Time (minutes) } & \text { E } & \mathrm{pH} \\ 280 & 0.0258 & \\ 280 & 0.0258 & 4.9\end{array}$




\section{SUIATIOIV}

It can be seen from a conparison of experiments 6 and 8 that the oxidation buffer had a definite effect on the potentials of the potentials of the ferri-ferro electrode. Without the oxidation buffer, the potential steadily as increased amounts of ferrous ions were added, but with the oxidation bufier the fall in potential was arrested at a certain point, depending on conditions affecting the solution being tested and the potentials rose thereafter with increased amounts of the ferrous ions.

The effect of acid on the buffered ferri-ferro electrode was to increase the potential of the electrode at all times under any given conditions. This was directly opposed to the findins of investifators (2) who worked with unbuffered solutions. Thus an increase of the hysurocen-ion coneentration seened to cause an attack on the buffer rether than an atteck on the ferrous or ferric ions directly. Temperature ef ect on this eloctrode (ferri-ferro) was ono of constant drop in obential regardess of concentration of ferrous or ferric ions. The difference in potential of the three solutions tested secmed to be ofiected more by the hydron-ion concentration than the proportions of ferrio to ferrous ions.

The effect of licht upon the compound in question was studied only qualitatively. Fron this study it was noticed that (1) aftor an initial sharp fall in potential, the fall practically lovellod out and with but one exception 
the potential never rose after the rays of this lamp struck the solution; (a) the falling of potential continued neither as long, nor did tho zotential decrease as much in the solution that contained the acid.

Thus it may be concluded from these studies that the hydrocen-ion concentration was of primary importance in the bufered ferri-ferro eloctrode. It may be seen that with solutions under the same aven conditions, the one with the hicher hydrocen-ion concentration also had the lif her rotenti住. 


\title{
BIBLIOGRAPHY
}

\author{
1. Bull. Bureau of Standards 5,336 (1909) \\ 2. 3. F. Carter 8. F. Olews - Journ. Of Chen. \\ Soc. $125,1980-9(1024)$ \\ 3. S. P. Carter \& T. J. Glover - Joum. of Ehys. \\ Chem 39, 679-687 (1932) \\ 4. S. S. Gohen 2. T. S. Githens - Fhameotherapeutics \\ D. Appleton \& Co. - New York and London (1928), \\ p.p. 1253-1254. \\ 5. H. J. Creichton - Nectrochemistry - Vol. I. \\ "Principles" - John Viley \& Sons - New York (1035) \\ p.p. 241-250. \\ 6. I. A. Pales 8. A. Tuage - J. Am. Chem. Soc. 42 \\ 2453 (1920) \\ 7. F. H. Cetman \& F. Daniels - Outine of Theoretical \\ Chemistry - John Wiley Sons - New York (1037) \\ p.p. 417,420 . \\ 3. R. A. Cooch - qunitative Analyais - John mley \\ B Sons - Now Fork - (1016) p.p. 21-28 \\ S. I. J. Clovers - U. hen. Soo. 10-15 (1933) \\ 10. Haber \& Klemensievicz - Z. physin. chem., 67,385 \\ (1909) \\ 11. Hase - Z. anore. Chem. 155, 21 (1926) \\ 12. Huhres, J. An. Chem. Soc., 44, 2630 (1922) \\ 13. I. N. Kolthofi 2 w. J. Tomsiecl - Journ. of Fhys. \\ Chem. 39. $945-54$ (1934) \\ 14. MacInnes 2 Dole - Ind. Inf. Cham (Anal) 1, 57 (1928) \\ 15. Jichaelis \& Friedhein - J. An. Chom. Soo.; 51,382 \\ 394 (1929) \\ 16. Feters - Z. hysik. Mlem., 26, 193 (1398) \\ 17. 3. Popoff - Quanitative Analysis - F. Dlaliston's \\ Son \& Co. Fhilacielphia (1927) p.p. 36-41.
}


18. W. Reinders \& C. H. delinjer - Rec. trav. chim., 57, $594-603$ (1938)

19. T. Tr. Richards, Journ. of Am. Chem. Soc., 22, 144 (1900)

20. T. Solomonn - A Manual of Pharmacologj - i. B. Saunders Co. Thiladelphia anc London (1932) p. 1025

21. F. F. Talbott - Quanitative Chomical AnalysisThe liac rillan Co. Tiew Yorl (1933) p.p. 10-15

22. J. Thompson - The Photoninature - 1, no. 10,401 (1900)

23. 1. T. Thompson - Theoretical and Applied nlectro-

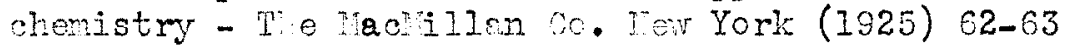

24. A. Prevors d J. Aubert. Comt. Rond. 95, 138-9 (1932)

25. I. C. Wood \& C. I. Lavall, I. T. Younlen, A Osol, J. rifith \& L. Corsienfield - Tharmeopoeica of the U. S. (Jinth Decennial Pevission) F. Blakiston's Son \& Co. Thiladelphia (1916) p. 465-466. 
ACKNOWLEDGMENT

I wish to express my sincere thanks

to Dr. Grover L. Corley, Professor

of Inorganic Chemistry, for his

everyready aid and helpfull suggest-

ions during the course of this in-

vestigation. 